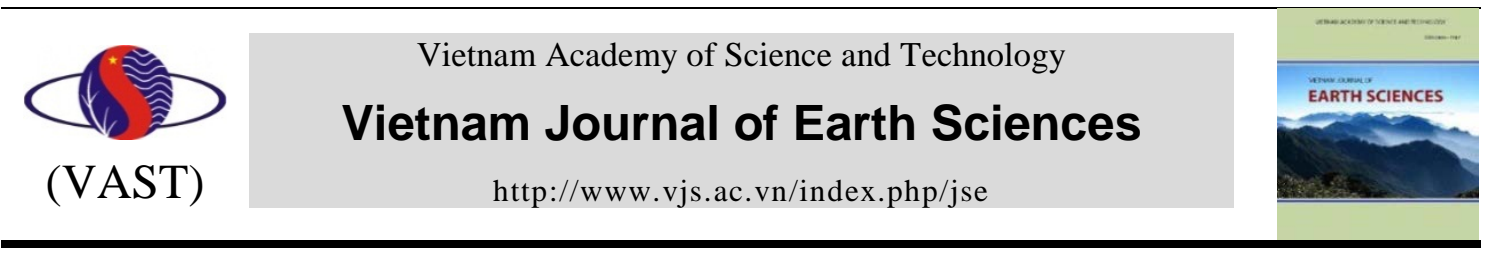

\title{
Petrology, geochemistry, and Sr, Nd isotopes of mantle xenolith in Nghia Dan alkaline basalt (West Nghe An): implications for lithospheric mantle characteristics beneath the region
}

\author{
Tran Thi Huong*, Nguyen Hoang \\ Institute of Geological Sciences, (VAST), 84 Chua Lang, Dong Da, Hanoi, Vietnam \\ Received 21 February 2018; Received in revised form 17 April 2018; Accepted 30 May 2018
}

\begin{abstract}
Study of petrological and geochemical characteristics of mantle peridotite xenoliths in Pliocene alkaline basalt in Nghia Dan (West Nghe An) was carried out. Rock-forming clinopyroxenes, the major trace element containers, were separated from the xenoliths to analyze for major, trace element and Sr-Nd isotopic compositions. The data were interpreted for source geochemical characteristics and geodynamic processes of the lithospheric mantle beneath the region. The peridotite xenoliths being mostly spinel-lherzolites in composition, are residual entities having been produced following partial melting events of ultramafic rocks in the asthenosphere. They are depleted in trace element abundance and Sr-Nd isotopic composition. Some are even more depleted as compared to mid-ocean ridge mantle xenoliths. Modelled calculation based on trace element abundances and their corresponding solid/liquid distribution coefficients showed that the Nghia Dan mantle xenoliths may be produced of melting degrees from 8 to 12\%. Applying various methods for two-pyroxene temperature- pressure estimates, the Nghia Dan mantle xenoliths show ranges of crystallization temperature and pressure, respectively, of $1010-1044^{\circ} \mathrm{C}$ and $13-14.2 \mathrm{kbar}$, roughly about $43 \mathrm{~km}$. A geotherm constructed for the mantle xenoliths showed a higher geothermal gradient as compared to that of in the western Highlands (Vietnam) and a conductive model, implying a thermal perturbation under the region. The calculated Sm-Nd model ages for the clinopyroxenes yielded 127 and 122 Ma. If the age is meaningful it suggests that there was a major geodynamic process occurred beneath Western Nghe An in the middle- Early Cretaceous that was large enough to cause perturbation in the evolutional trend of the Sm-Nd isotopic system.
\end{abstract}

Keywords: Nghia Dan; alkaline basalt; mantle xenolith; spinel-lherzolite; clinopyroxene.

(C2018 Vietnam Academy of Science and Technology

\section{Introduction}

\subsection{Alkaline basalt-borne mantle xenoliths}

Mantle xenoliths (inclusions) brought to the surface by alkaline basalts are residues formed following partial melting events of

*Corresponding author, Email: tranhuong.humg@gmail.com mantle peridotites in the upper mantle. These residual bodies are constituent components of the lithospheric mantle (Frey and Frinz, 1978; Nixon (Editor), 1987), dividing the conductive crust above and convective asthenosphere below (Anderson, 1994). Being dependent on the degree of partial melting of a fertile (primitive) mantle peridotite, the residual peridotite 
may be variously enriched/fertile or depleted/refractory.

The effect of partial melting experienced along with the complex mantle interactions in the lithospheric mantle is normally recorded and reflected by various radiogenic isotope systematics. Therefore, studying radiogenic isotope systematics and element geochemical characteristics of mantle peridotite residues, their formation and evolution history, in particularly, and of the lithospheric mantle, in general, may be revealed (Carlson and Lugmair, 1979, 1981; Carlson and Irving, 1994; Frey and Prinz, 1978; De Paolo, 1981; De Paolo et al., 2000; Menzies et al., 1987). Besides, study of Sm-Nd, Lu-Hf isotope systematics, which are persistent to external factors, in mantle peridotite residues one may be able to understand major geodynamic processes having occurred in the lithospheric mantle prior to their being brought to the surface by alkaline basalt (DePaolo and Wasserburg, 1976; DePaolo, 1981; McCulloch and Wasserburg, 1978; Nixon, 1987).

\subsection{Alkaline basalt in the Nghia Dan district}

Pliocene basaltic volcanism occurred in the Thai Hoa and other nearby communes of Nghia Dan district (West Nghe An) and Xuan Binh, Nhu Xuan district (Thanh Hoa) (Figure 1). The volcanism is viewed as part of the widely spread Cenozoic basaltic volcanism occurred at many localities in southeast Asia (Barr and McDonald, 1981; Whitford-Stark, 1987; Zhou and Mukasa, 1997). In Vietnam, the Cenozoic basalt occurred voluminously in the Western Highlands, south-Central region, along the coastline and in the continental shelf of the East Vietnam Sea (Nguyen and Nguyen, 1980; Barr and McDonald, 1981; Gorshkov, 1981; Gorshkov et al., 1984; Whitford-Stark, 1987; Tu et al., 1991, 1992; Flower et al., 1991; Fedorov and Koloskov, 2005; Hoang et al., 2014; An et al., 2017; Hoang-
Thi et al., 2018). The volcanism occurred long after the cessation of East Vietnam Sea opening tectonics (32-16 Ma) ( $\mathrm{Li}$ et al., 2014 and references therein). The latter, termed as extrusion tectonics, has been viewed as a consequence of India - Eurasian hard collision about 60-40 Ma (Tapponnier et al., 1982; Briais et al., 1993; Lee and Lawver, 1995), igniting left lateral strike slip along the Ailao Shan - Red River fault zone and counterclockwise rotation of the Indochina block, and might lead to the opening of East Vietnam Sea (Tapponnier et al., 1982, 1990). The extrusion concept of marginal sea opening is controversial (e.g., Cung et al., 1998; see summaries in Li et al., 2014, 2015); however, this is out of our scope to debate.

Like many Cenozoic volcanic fields in the Western Highlands and elsewhere in southCentral region of Vietnam, the basaltic rocks in Nghia Dan (and Nhu Xuan) (thereafter Nghia Dan center) occur along or at the intersection of the regional fault systems. The volcanism appears as monogenetic volcanoes, forming lava covers with varying thicknesses, from a few meters to hundreds of meters. Depending on the size of volcanoes, the lava cover varies from a few square kilometers to tens of square kilometers in area. Volcanoes being tens of meters to more than 250 meters high are scattered in Nghia Son (Mt. Nui Tien), Nghia Lam (Mt. Nui Hang), Nghia My (Mt. Doi Tro, Doi Troc, Ke Lui), and Xuan Binh (Mt. Nui Ro), etc. The basalt occurs as massive or porous. Rectangular- and pentagon-columnar basalts are seen at Mt. Ke Lui (Hoang et al., 2014) (Figure 2). Heavily porous basaltic rocks (up to 50 vol.\% vesicles from several millimeters to more than one centimeters in diameter) are subject to strong weathering, forming a crust that is widely used as cement additive for many local cement factories. Two basaltic samples collected along the Ho Chi Minh trail in the Nghia My 
commune, south of Thai Hoa town, show $\mathrm{Ar} / \mathrm{Ar}$ ages of $3.54 \mathrm{Ma}$ (Cung et al., 1998). Overall, age of Nghia Dan basalt is marked as
(Pliocene) on the regional geological map at scale of 1:200,000 (Vinh Sheet, Geological map of Vietnam).

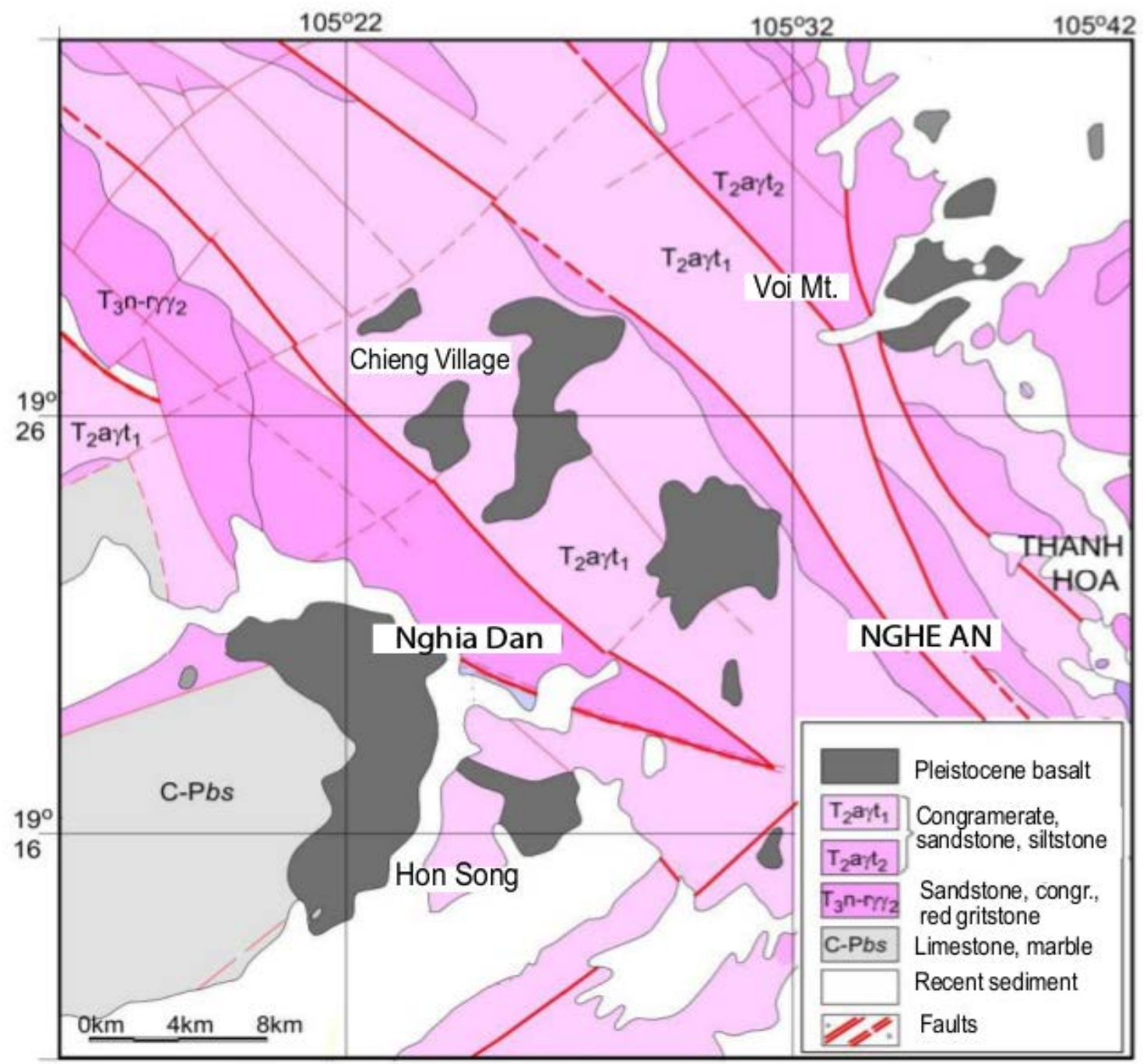

Figure 1. Distribution scheme of the Pliocene basalt in Nghia Dan (Nghe An) and Nhu Xuan (Thanh Hoa); redrawn from Geological Map of Vietnam at 1:200.000 scale

The Nghia Dan basalts are low in $\mathrm{SiO}_{2}$ (wt.\%), very high in $\mathrm{TiO}_{2}$ (wt.\%) and high in the total alkali $\left(\mathrm{K}_{2} \mathrm{O}+\mathrm{Na}_{2} \mathrm{O}\right)$ that they plot in the alkaline field in the classification diagram (Hoang et al., 2014). Nghia Dan Pliocene basalts Nghia Dan have high abundances of incompatible and rare earth elements, they are even higher as compared with those in young $(<1 \mathrm{Ma})$ alkaline basalts in Pleiku, Western Highlands, used to view as the most enriched Cenozoic basalts in Vietnam (Hoang et al., 2014). Using Nghia Dan trace element abundances along with their corresponding $\mathrm{Sr}, \mathrm{Nd}$ and $\mathrm{Pb}$ isotopic compositions for mantle 
source modelling, Hoang et al. (2014) concluded that the Nghia Dan alkaline basalts were produced by partial melting of spinel peridotites in the asthenosphere (e.g. Johnson et al., 1990; Workman and Hart, 2005).

As reported elsewhere in the world, in Vietnam mantle xenoliths are found only in highly alkaline basalts (Ne-normative $>5$ vol.\%). Mantle xenoliths are discovered at two locations around Thai Hoa township, at
Nghia My (Mt. Ke Lui) and Nghia Loi communes (Figure 2a). The mantle xenoliths occur in various sizes, from a few centimeters up to $15 \mathrm{~cm}$ by $10 \mathrm{~cm}$. They are coarsegrained, massive, comprising mostly olivine, up to $2 \mathrm{~mm}$ by $1 \mathrm{~mm}$ in size. The xenoliths, clearly distinguishable on the dark basalt background, are dark green to light green, some turned to brown as an effect of weathering (Figure 2b).
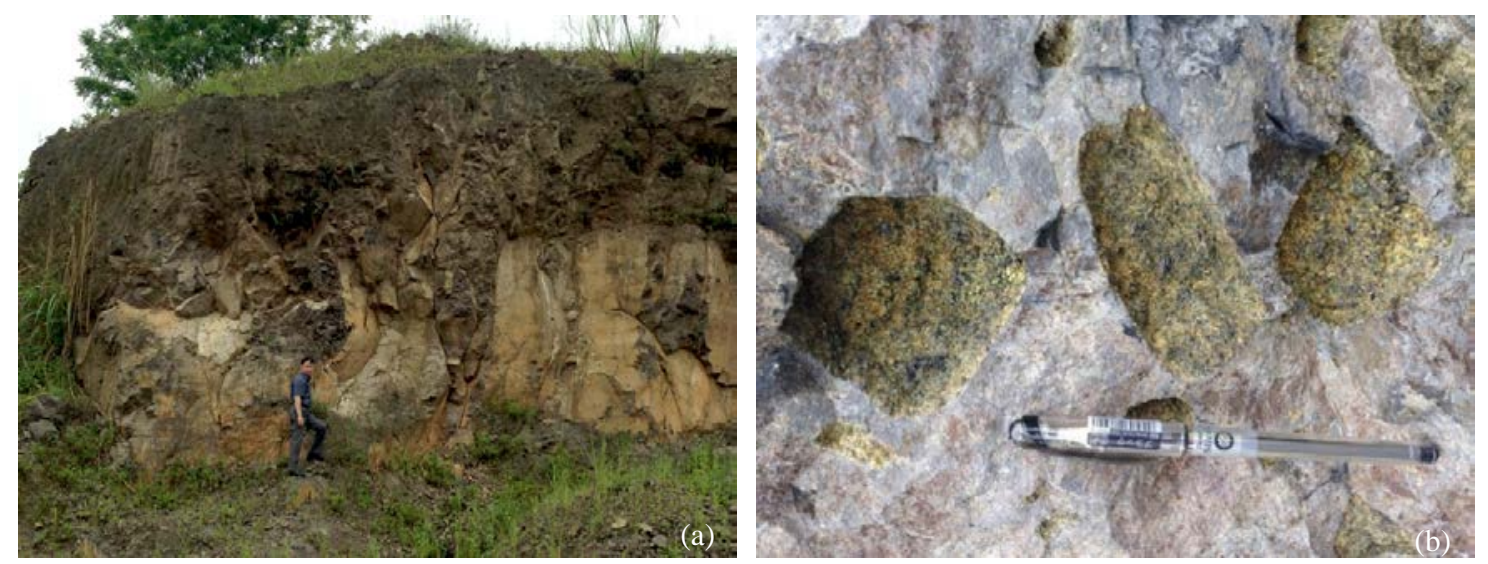

Figure 2. Mt. Ke Lui (Nghia My, a), where mantle xenoliths found (b)

Mantle xenolith samples were collected in alkaline basalt at two locations in Nghia My and Nghia Loi communes for this study. The whole rock samples were processed for petrographic study and electronic probe microanalysis (EPMA) for rock-forming minerals. The trace element and Sr-Nd isotopic analysis were performed on clinopyroxenes separated from the xenolith samples. The data were interpreted in terms of petrological and geochemical characteristics of the lithospheric mantle and its associated major regional geodynamic processes.

\section{Sample processing and analytical proce- dures}

The samples were processed for petrographic study under a polarizing microscope, also for acquisition of rock-forming mineral geochemical compositions using electron probe microscopic analysis (EPMA). The mantle xenoliths are spinel-lherzolites, coarsegrained, xenogranular or metamorphic textured. The crystals are compacted with smooth rims, or round-shaped, certainly reflecting melting experience. The most representative mineral assemblage is (in vol.\%) olivine (Ol): 70-80, orthopyroxene (Opx): 1925, clinopyroxene (Cpx): 3-5, and spinel (Sp): $<2$. The modal data were collected in thin sections and counting $>500$ points on a $1 \mathrm{~mm}$ grid (Figure 3). The olivine is lemon yellow, or green to brightly green, coarse-grained (up to 2 by $2 \mathrm{~mm}$ ), partially corroded. The orthopyroxene is grayish dark, glassy black. The crystals with clear cleavages are tablet, elongated with sizes up to 2 by $1 \mathrm{~mm}$, anhedral or semieuhedral. The clinopyroxene is dark green, ir- 
regular-shaped, small-sized ( $<0.5$ by $0.2 \mathrm{~mm}$ ), distributed between the co-existent orthopyroxene grains. The spinel is darkish red, dark brown, irregularly shaped, distributed in the interstices between, or included in, large olivine crystals (Figure 4).
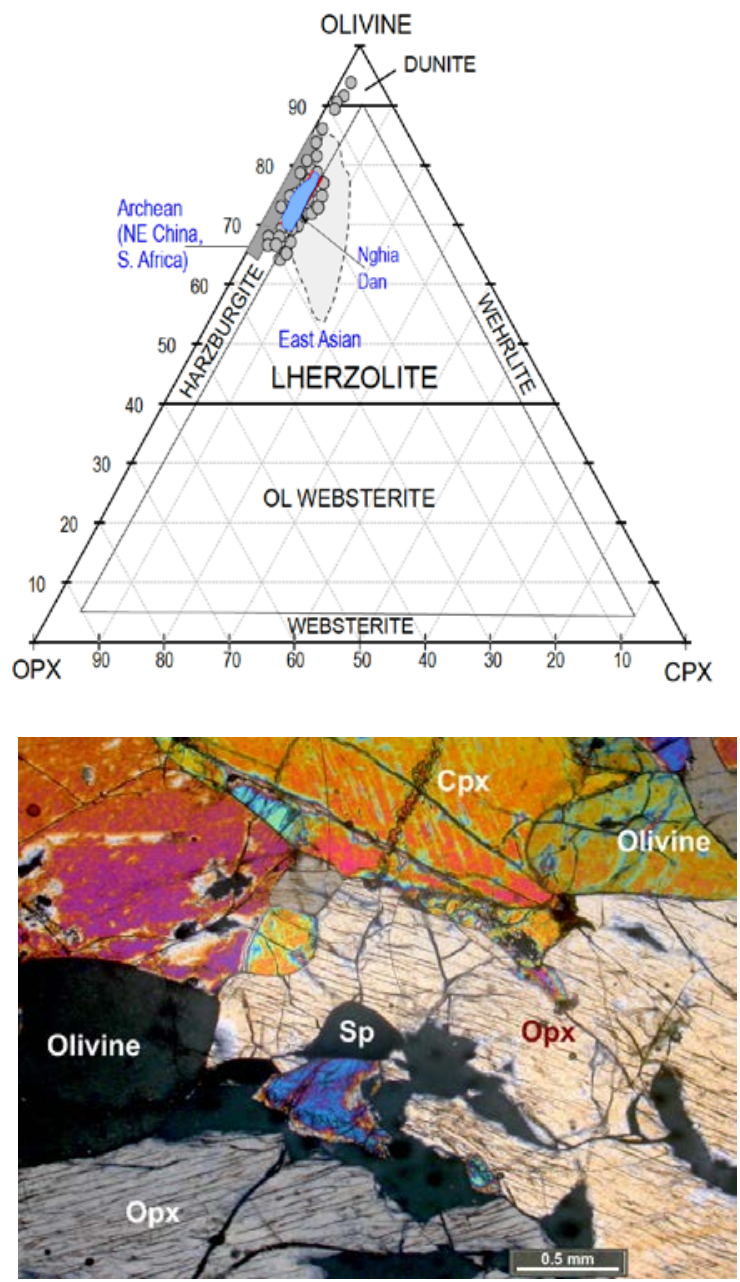

$\leftarrow$ Figure 3. Classification diagram of mantle peridotites, showing mantle xenoliths in alkaline basalts in Vietnam; Nghia Dan mantle xenoliths filled, red squares

Five representative samples were chosen among the collected samples in the Nghia My and Nghia Loi communes. The samples were processed to measure for major elements of the rock-forming minerals using a JEOL 8800 Electron Probe Microanalyzer (EPMA) at the Geological Survey of Japan (Tsukuba, Japan). The accuracy of the analysis was estimated between \pm 2 and $\pm 3 \%$ based on the repeated measurements of JEOL standards using natural minerals such as jadeite $(\mathrm{Na})$, albite $(\mathrm{K})$, kyanite $(\mathrm{Al})$, wollastonite (Ca, $\mathrm{Si})$, forsterite $(\mathrm{Mg})$, rutile $(\mathrm{Ti})$ and manganese ferrite (Fe) etc. Data for coexisting pyroxenes were used to calculate for crystallization temperatures using two pyroxene geothermometer by Wells (1977), Brey and Kohler (1990), Putirka et al. (2003), and Putirka (2008, 2017). The data are shown in Table 1.

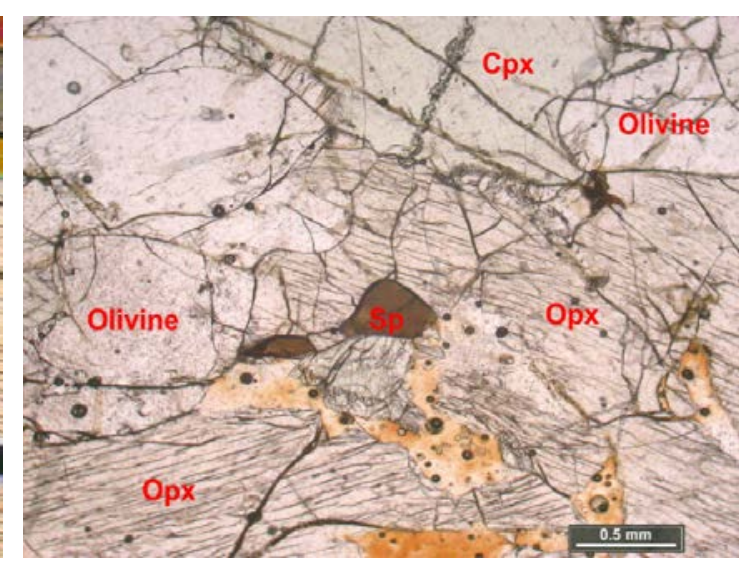

Figure 4. Photomicrograph of a spinel-lherzolite xenolith with xenogranular texture recovered at Mt. Ke Lui (Nghia My) showing a mineral assemblage comprising olivine, orthopyroxene, clinopyroxene and spinel: cross polarized (left), plain polarized (right) 
Tran Thi Huong and Nguyen Hoang/Vietnam Journal of Earth Sciences 40 (2018)

Table 1. Major element concentrations (wt.\%) of rock-forming minerals of Nghia Dan mantle xenoliths

\begin{tabular}{|c|c|c|c|c|c|c|c|c|}
\hline & \multicolumn{4}{|c|}{ B040313-16Сpx/1 (n=3) } & \multicolumn{4}{|c|}{ B040313-16Сpx/2 (n=5) } \\
\hline & $\mathrm{OL}$ & SP & CPX & OPX & $\mathrm{OL}$ & SP & CPX & OPX \\
\hline$\overline{\mathrm{SiO}_{2}}$ & 40.60 & 0.05 & 52.32 & 54.89 & 40.58 & 0.03 & 52.32 & 54.88 \\
\hline $\mathrm{TiO}_{2}$ & 0.00 & 0.21 & 0.61 & 0.22 & 0.03 & 0.15 & 0.61 & 0.12 \\
\hline $\mathrm{Al}_{2} \mathrm{O}_{3}$ & 0.01 & 59.80 & 7.37 & 5.07 & 0.01 & 59.71 & 7.37 & 4.90 \\
\hline $\mathrm{FeO}$ & 10.21 & 11.63 & 3.27 & 6.69 & 10.18 & 11.46 & 3.27 & 6.73 \\
\hline $\mathrm{MnO}$ & 0.15 & 0.12 & 0.09 & 0.14 & 0.12 & 0.11 & 0.09 & 0.17 \\
\hline $\mathrm{MgO}$ & 48.61 & 19.47 & 14.74 & 31.74 & 48.59 & 19.73 & 14.74 & 31.93 \\
\hline $\mathrm{CaO}$ & 0.05 & 0.00 & 19.18 & 0.70 & 0.06 & 0.01 & 19.18 & 0.71 \\
\hline $\mathrm{Na}_{2} \mathrm{O}$ & 0.00 & 0.00 & 1.69 & 0.09 & 0.01 & 0.00 & 1.69 & 0.12 \\
\hline $\mathrm{K}_{2} \mathrm{O}$ & 0.00 & 0.00 & 0.00 & 0.01 & 0.00 & 0.00 & 0.00 & 0.00 \\
\hline $\mathrm{Cr}_{2} \mathrm{O}_{3}$ & 0.02 & 8.33 & 0.69 & 0.33 & 0.01 & 8.44 & 0.69 & 0.33 \\
\hline $\mathrm{NiO}$ & 0.35 & 0.38 & 0.05 & 0.12 & 0.40 & 0.37 & 0.05 & 0.09 \\
\hline Total & 100 & 100 & 100 & 100 & 100 & 100 & 100 & 100 \\
\hline$M g \#$ & 89.5 & 74.9 & 88.9 & 89.4 & 89.5 & 75.4 & 88.9 & 89.4 \\
\hline $\mathrm{Cr \#}$ & & 8.5 & 5.9 & 4.2 & & 8.7 & 5.9 & 4.4 \\
\hline Fs & & & 6.0 & 10.4 & & & 6.0 & 10.4 \\
\hline En & & & 48.5 & 88.2 & & & 48.5 & 88.2 \\
\hline \multirow[t]{3}{*}{ Wo } & & & 45.4 & 1.4 & & & 45.4 & 1.4 \\
\hline & \multicolumn{4}{|c|}{ B040313-16Cpx/3 (n=3) } & \multicolumn{4}{|c|}{ B040313-16Cpx/4 (n=3) } \\
\hline & $\mathrm{OL}$ & SP & CPX & OPX & $\mathrm{OL}$ & SP & CPX & OPX \\
\hline$\overline{\mathrm{SiO}_{2}}$ & 40.70 & 0.03 & 52.36 & 55.16 & 40.49 & 0.07 & 51.90 & 54.78 \\
\hline $\mathrm{TiO}_{2}$ & 0.00 & 0.17 & 0.66 & 0.13 & 0.02 & 0.19 & 0.68 & 0.12 \\
\hline $\mathrm{Al}_{2} \mathrm{O}_{3}$ & 0.02 & 60.05 & 7.28 & 4.78 & 0.04 & 59.55 & 7.31 & 4.79 \\
\hline $\mathrm{FeO}$ & 10.33 & 11.43 & 3.01 & 6.44 & 10.37 & 11.56 & 3.29 & 6.63 \\
\hline $\mathrm{MnO}$ & 0.11 & 0.07 & 0.10 & 0.14 & 0.15 & 0.13 & 0.11 & 0.16 \\
\hline $\mathrm{MgO}$ & 48.43 & 19.57 & 14.82 & 32.16 & 48.47 & 19.81 & 15.00 & 32.35 \\
\hline $\mathrm{CaO}$ & 0.06 & 0.03 & 19.39 & 0.69 & 0.08 & 0.01 & 19.26 & 0.66 \\
\hline $\mathrm{Na}_{2} \mathrm{O}$ & 0.00 & 0.01 & 1.62 & 0.10 & 0.02 & 0.01 & 1.74 & 0.10 \\
\hline $\mathrm{K}_{2} \mathrm{O}$ & 0.00 & 0.00 & 0.01 & 0.00 & 0.00 & 0.00 & 0.01 & 0.00 \\
\hline $\mathrm{Cr}_{2} \mathrm{O}_{3}$ & 0.00 & 8.29 & 0.74 & 0.28 & 0.00 & 8.28 & 0.67 & 0.27 \\
\hline $\mathrm{NiO}$ & 0.35 & 0.35 & 0.02 & 0.12 & 0.36 & 0.40 & 0.04 & 0.11 \\
\hline Total & 100 & 100 & 100 & 100 & 100 & 100 & 100 & 100 \\
\hline$M g \#$ & 89.3 & 75.3 & 89.8 & 89.9 & 89.3 & 75.3 & 89.0 & 89.7 \\
\hline Cr\# & & 8.5 & 6.4 & 3.7 & & 8.5 & 5.8 & 3.7 \\
\hline Fs & & & 5.5 & 10.0 & & & 6.0 & 10.2 \\
\hline En & & & 48.7 & 88.7 & & & 48.9 & 88.5 \\
\hline \multirow[t]{3}{*}{ Wo } & & & 45.8 & 1.4 & & & 45.1 & 1.3 \\
\hline & \multicolumn{4}{|c|}{ B040313-16Cpx/5 (n=5) } & \multicolumn{4}{|c|}{ A040313-7Cpx/1 $(n=3)$} \\
\hline & $\mathrm{OL}$ & $\mathrm{SP}$ & $\mathrm{CPX}$ & OPX & $\mathrm{OL}$ & $\mathrm{SP}$ & CPX & OPX \\
\hline $\mathrm{SiO}_{2}$ & 40.90 & 0.06 & 51.84 & 55.22 & 40.56 & 0.03 & 52.37 & 54.65 \\
\hline $\mathrm{TiO}_{2}$ & 0.00 & 0.15 & 0.62 & 0.20 & 0.00 & 0.17 & 0.61 & 0.15 \\
\hline $\mathrm{Al}_{2} \mathrm{O}_{3}$ & 0.04 & 59.66 & 7.49 & 4.76 & 0.01 & 60.05 & 7.11 & 4.96 \\
\hline $\mathrm{FeO}$ & 10.17 & 11.51 & 3.11 & 6.40 & 10.41 & 11.43 & 3.26 & 6.82 \\
\hline $\mathrm{MnO}$ & 0.14 & 0.12 & 0.08 & 0.07 & 0.13 & 0.07 & 0.08 & 0.12 \\
\hline $\mathrm{MgO}$ & 48.32 & 19.62 & 14.86 & 32.15 & 48.50 & 19.57 & 14.61 & 32.09 \\
\hline $\mathrm{CaO}$ & 0.06 & 0.01 & 19.62 & 0.67 & 0.08 & 0.03 & 19.53 & 0.63 \\
\hline $\mathrm{Na}_{2} \mathrm{O}$ & 0.01 & 0.03 & 1.64 & 0.14 & 0.00 & 0.01 & 1.70 & 0.09 \\
\hline $\mathrm{K}_{2} \mathrm{O}$ & 0.00 & 0.00 & 0.02 & 0.00 & 0.00 & 0.00 & 0.00 & 0.01 \\
\hline $\mathrm{Cr}_{2} \mathrm{O}_{3}$ & 0.01 & 8.46 & 0.65 & 0.27 & 0.00 & 8.29 & 0.69 & 0.36 \\
\hline $\mathrm{NiO}$ & 0.34 & 0.38 & 0.08 & 0.12 & 0.31 & 0.35 & 0.03 & 0.12 \\
\hline
\end{tabular}


Vietnam Journal of Earth Sciences, 40(3), 207-227

\begin{tabular}{|c|c|c|c|c|c|c|c|c|}
\hline & \multicolumn{4}{|c|}{ B040313-16Cpx/5 (n=5) } & \multicolumn{4}{|c|}{ A040313-7Cpx/1 (n= 3) } \\
\hline & OL & SP & $\mathrm{CPX}$ & OPX & OL & SP & $\mathrm{CPX}$ & OPX \\
\hline Total & 100 & 100 & 100 & 100 & 100 & 100 & 100 & 100 \\
\hline$M g \#$ & 89.4 & 75.2 & 89.5 & 90.0 & 89.3 & 75.3 & 88.9 & 89.3 \\
\hline $\mathrm{Cr \#}$ & & 8.7 & 5.5 & 3.7 & & 8.5 & 6.1 & 4.7 \\
\hline Fs & & & 5.7 & 9.9 & & & 6.0 & 10.5 \\
\hline En & & & 48.4 & 88.7 & & & 47.9 & 88.2 \\
\hline \multirow[t]{3}{*}{ Wo } & & & 46.0 & 1.3 & & & 46.1 & 1.3 \\
\hline & \multicolumn{4}{|c|}{ A040313-7Cpx/2 (n= 3) } & \multicolumn{4}{|c|}{ A040313-7Cpx/3 $(n=4)$} \\
\hline & $\mathrm{OL}$ & SP & $\mathrm{CPX}$ & OPX & $\mathrm{OL}$ & SP & $\mathrm{CPX}$ & OPX \\
\hline $\mathrm{SiO}_{2}$ & 40.35 & 0.07 & 52.17 & 54.65 & 40.62 & 0.06 & 52.27 & 54.85 \\
\hline $\mathrm{TiO}_{2}$ & 0.02 & 0.19 & 0.68 & 0.15 & 0.00 & 0.15 & 0.63 & 0.14 \\
\hline $\mathrm{Al}_{2} \mathrm{O}_{3}$ & 0.03 & 59.55 & 7.23 & 4.96 & 0.06 & 59.66 & 7.41 & 4.86 \\
\hline $\mathrm{FeO}$ & 10.25 & 11.56 & 3.30 & 6.82 & 10.26 & 11.51 & 2.89 & 6.65 \\
\hline $\mathrm{MnO}$ & 0.17 & 0.13 & 0.08 & 0.12 & 0.17 & 0.12 & 0.07 & 0.14 \\
\hline $\mathrm{MgO}$ & 48.75 & 19.81 & 14.79 & 32.09 & 48.44 & 19.62 & 14.77 & 32.21 \\
\hline $\mathrm{CaO}$ & 0.06 & 0.01 & 19.34 & 0.63 & 0.05 & 0.01 & 19.47 & 0.68 \\
\hline $\mathrm{Na}_{2} \mathrm{O}$ & 0.04 & 0.01 & 1.64 & 0.09 & 0.01 & 0.03 & 1.74 & 0.10 \\
\hline $\mathrm{K}_{2} \mathrm{O}$ & 0.02 & 0.00 & 0.00 & 0.01 & 0.01 & 0.00 & 0.01 & 0.00 \\
\hline $\mathrm{Cr}_{2} \mathrm{O}_{3}$ & 0.00 & 8.28 & 0.68 & 0.36 & 0.01 & 8.46 & 0.69 & 0.28 \\
\hline $\mathrm{NiO}$ & 0.31 & 0.40 & 0.07 & 0.12 & 0.37 & 0.38 & 0.05 & 0.11 \\
\hline Total & 100 & 100 & 100 & 100 & 100 & 100 & 100 & 100 \\
\hline$M g \#$ & 89.5 & 75.3 & 88.9 & 89.3 & 89.4 & 75.2 & 90.1 & 89.6 \\
\hline $\mathrm{Cr} \#$ & & 8.5 & 6.0 & 4.7 & & 8.7 & 5.9 & 3.7 \\
\hline Fs & & & 6.1 & 10.5 & & & 5.3 & 10.2 \\
\hline En & & & 48.4 & 88.2 & & & 48.6 & 88.4 \\
\hline \multirow[t]{3}{*}{ Wo } & & & 45.5 & 1.3 & & & 46.1 & 1.3 \\
\hline & \multicolumn{4}{|c|}{ A040313-7Cpx/4 (n= 5) } & \multicolumn{4}{|c|}{ A040313-7Cpx/5 (n= 3) } \\
\hline & $\mathrm{OL}$ & SP & $\mathrm{CPX}$ & OPX & $\mathrm{OL}$ & SP & $\mathrm{CPX}$ & OPX \\
\hline $\mathrm{SiO}_{2}$ & 40.87 & 0.03 & 52.51 & 54.78 & 40.63 & 0.05 & 52.17 & 55.22 \\
\hline $\mathrm{TiO}_{2}$ & 0.03 & 0.17 & 0.61 & 0.12 & 0.02 & 0.21 & 0.68 & 0.20 \\
\hline $\mathrm{Al}_{2} \mathrm{O}_{3}$ & 0.00 & 60.05 & 7.40 & 4.79 & 0.00 & 59.80 & 7.23 & 4.76 \\
\hline $\mathrm{FeO}$ & 10.17 & 11.43 & 2.82 & 6.63 & 10.22 & 11.63 & 3.30 & 6.40 \\
\hline $\mathrm{MnO}$ & 0.15 & 0.07 & 0.07 & 0.16 & 0.13 & 0.12 & 0.08 & 0.07 \\
\hline $\mathrm{MgO}$ & 48.39 & 19.57 & 14.85 & 32.35 & 48.54 & 19.47 & 14.79 & 32.15 \\
\hline $\mathrm{CaO}$ & 0.06 & 0.03 & 19.33 & 0.66 & 0.04 & 0.00 & 19.34 & 0.67 \\
\hline $\mathrm{Na}_{2} \mathrm{O}$ & 0.00 & 0.01 & 1.70 & 0.10 & 0.01 & 0.00 & 1.64 & 0.14 \\
\hline $\mathrm{K}_{2} \mathrm{O}$ & 0.00 & 0.00 & 0.00 & 0.00 & 0.00 & 0.00 & 0.00 & 0.00 \\
\hline $\mathrm{Cr}_{2} \mathrm{O}_{3}$ & 0.00 & 8.29 & 0.69 & 0.27 & 0.03 & 8.33 & 0.68 & 0.27 \\
\hline $\mathrm{NiO}$ & 0.33 & 0.35 & 0.02 & 0.11 & 0.39 & 0.38 & 0.07 & 0.12 \\
\hline Total & 100 & 100 & 100 & 100 & 100 & 100 & 100 & 100 \\
\hline Mg\# & 89.5 & 75.3 & 90.4 & 89.7 & 89.4 & 74.9 & 88.9 & 90.0 \\
\hline $\mathrm{Cr \#}$ & & 8.5 & 5.9 & 3.7 & & 8.5 & 6.0 & 3.7 \\
\hline Fs & & & 5.2 & 10.2 & & & 6.1 & 9.9 \\
\hline En & & & 48.9 & 88.5 & & & 48.4 & 88.7 \\
\hline Wo & & & 45.8 & 1.3 & & & 45.5 & 1.3 \\
\hline
\end{tabular}


The trace element and Sr-Nd isotopic compositions were acquired on separated clinopyroxenes from two presentative large (5x $10 \times 10 \mathrm{~cm})$ spinel-lherzolite samples collected from Mt. Ke Rui and Nghia Loi (Figure 2). The clinopyroxene separation was treated as follows. About 50g of the mantle xenoliths were crushed and ground, followed by $1 \mathrm{~mm}$ sized sieving. The sieved particles were cleaned ultrasonically for about 30 minutes, followed by multiple rinse with clean water. The cleaned samples were dried in an oven at $90^{\circ} \mathrm{C}$ for about 1 hour. The samples were left to cool. Clinopyroxenes were then hand-picked under a stereo binocular microscope. The clinopyroxene separates were again roughly ground, ultrasonically cleaned, dried and hand-picked to eliminate any other minerals than clinopyroxene.

About 100mg of clinopyroxene separates were weighed in $15 \mathrm{ml}$ Teflon beakers, ready for dissolution. For sample dissolution, a mixture of $1 \mathrm{ml}$ and $2 \mathrm{ml}$, respectively, of concentrated $\mathrm{HNO}_{3}$ and $\mathrm{HF}$ was added to the beak- ers, capped and left on a hotplate at about $140^{\circ} \mathrm{C}$ for two days, followed by complete evaporation. The dried samples were added with $3 \mathrm{ml}$ of $7 \mathrm{M} \mathrm{HNO}_{3}$, capped and left on a hotplate at about $80^{\circ} \mathrm{C}$ for an overnight to ensure the samples were dissolved completely. The samples were evaporated, weighed, then diluted with $6 \mathrm{ml}$ of $0.3 \mathrm{M} \mathrm{HNO}_{3}$. An aliquot of about 3ml (ca. 50mg) of the sample was taken for trace element concentration determination using a Neptune Elemental quadrupole inductively coupled plasma mass spectrometer (QICP-MS) at the Department of Physics and Earth Sciences, University of the Ryukyus, Okinawa, Japan. The trace element compositions are shown in Table 2.

The remaining sample solutions were treated for chromatographic work to extract $\mathrm{Sr}$ and Nd elements. The ${ }^{87} \mathrm{Sr} /{ }^{86} \mathrm{Sr},{ }^{143} \mathrm{Nd} /{ }^{144} \mathrm{Nd}$ isotopic ratios were acquired using a VG Sector 54 Thermo- Ionization Mass Spectrometer (TIMS) at the Geological Survey of Japan, Tsukuba, Japan. The data are shown in Table 2.

Table 2. Trace element and Sm-Nd-Sr isotopic compositions of clinopyroxene separates from Nghia Dan spinellherzolite xenoliths

\begin{tabular}{|c|c|c|c|c|}
\hline Sample & В040313-16Срх & A040313-7Cрх & A040213-16A & A040313-7B \\
\hline Location & Nghia Dan & Nghia Dan & Nghia Dan & Nghia Dan \\
\hline Latitude & N19²5'0.1" & N19²1'26" & N19²5'00.1" & N19²1'26" \\
\hline Longitude & E105²6'07.9" & E105³1'37" & E105²6'07.9" & E10531'37" \\
\hline Sm (ppm) & 0.349 & 0.328 & 11.24 & 11.33 \\
\hline Nd (ppm) & 0.709 & 0.518 & 64.3 & 64.74 \\
\hline${ }^{147} \mathrm{Sm} /{ }^{144} \mathrm{Nd}$ & 0.304 & 0.391 & 0.121 & 0.108 \\
\hline${ }^{143} \mathrm{Nd} /{ }^{144} \mathrm{Nd}$ & 0.513225 & 0.513292 & 0.512776 & 0.512773 \\
\hline $\mathrm{T}_{(\mathrm{DM})}$ & $1.27 \mathrm{E}+08$ & $1.22 \mathrm{E}+08$ & & \\
\hline$\varepsilon_{\mathrm{Nd}}$ & 11.45 & 12.76 & 2.69 & 2.65 \\
\hline${ }^{87} \mathrm{Sr} /{ }^{86} \mathrm{Sr}$ & 0.702493 & 0.702694 & 0.704576 & 0.704564 \\
\hline \multicolumn{5}{|l|}{ In $p p m$} \\
\hline $\mathrm{Rb}$ & 0.56 & 0.49 & 54.3 & 89.65 \\
\hline $\mathrm{Sr}$ & 25.83 & 23.66 & 1779 & 1898.75 \\
\hline $\mathrm{Y}$ & 15.77 & 16.12 & 29.5 & 28.80 \\
\hline $\mathrm{Zr}$ & 15.86 & 16.45 & 366 & 320.85 \\
\hline $\mathrm{Nb}$ & 0.43 & 0.36 & 137.2 & 110.29 \\
\hline Cs & 0.004 & 0.004 & 0.58 & 1.23 \\
\hline $\mathrm{Ba}$ & 3.27 & 2.89 & 723 & 711.58 \\
\hline
\end{tabular}


Vietnam Journal of Earth Sciences, 40(3), 207-227

\begin{tabular}{|c|c|c|c|c|}
\hline Sample & В040313-16Срх & A040313-7Срх & A040213-16A & A040313-7B \\
\hline $\mathrm{La}$ & 0.40 & 0.34 & 75.9 & 77.48 \\
\hline $\mathrm{Ce}$ & 1.61 & 1.35 & 152.6 & 149.91 \\
\hline $\operatorname{Pr}$ & 0.34 & 0.33 & 17 & 16.99 \\
\hline $\mathrm{Nd}$ & 0.709 & 0.518 & 64.3 & 64.74 \\
\hline Sm & 0.349 & 0.328 & 11.24 & 11.33 \\
\hline $\mathrm{Eu}$ & 0.52 & 0.51 & 3.4 & 3.50 \\
\hline Gd & 1.61 & 1.67 & 10.97 & 10.31 \\
\hline $\mathrm{Tb}$ & 0.37 & 0.39 & 1.246 & 1.30 \\
\hline Dy & 2.55 & 2.32 & 5.73 & 6.19 \\
\hline Ho & 0.58 & 0.56 & 0.998 & 1.09 \\
\hline $\mathrm{Er}$ & 1.69 & 1.65 & 2.42 & 2.98 \\
\hline $\mathrm{Tm}$ & 0.24 & 0.23 & 0.319 & 0.37 \\
\hline $\mathrm{Yb}$ & 1.55 & 1.52 & 1.98 & 2.30 \\
\hline $\mathrm{Lu}$ & 0.22 & 0.22 & 0.264 & 0.32 \\
\hline $\mathrm{Hf}$ & 0.63 & 0.65 & 6.55 & 6.22 \\
\hline Та & 0.05 & 0.05 & 6.83 & 6.06 \\
\hline $\mathrm{Pb}$ & 0.11 & 0.08 & 4.35 & 3.34 \\
\hline Th & 0.04 & 0.04 & 8.46 & 9.80 \\
\hline $\mathrm{U}$ & 0.03 & 0.03 & 2.27 & 2.49 \\
\hline V & 229.8 & 236.6 & 206 & 200 \\
\hline $\mathrm{Cr}$ & 4,014 & 3,898 & 294 & 165 \\
\hline $\mathrm{Ni}$ & 411.7 & 392.5 & 244 & 159 \\
\hline
\end{tabular}

\section{Analytical results}

\subsection{Geochemistry of the mantle xenoliths}

Note that most of the mantle xenoliths are spinel lherzolites. Geochemical compositions of their rock-forming minerals are relatively uniform regardless of being collected from two sites about $10 \mathrm{~km}$ apart. Geochemical similarity is also seen in alkaline basalts sampled from the two sites (Table 2).

\subsubsection{Spinel and olivine relationship}

Geochemically compositional characteristics of mantle xenoliths are reflected by the geochemistry of their rock-forming minerals (Figure 4). The olivine content in the Nghia Dan mantle xenoliths varies from (about) 70 to 80 vol.\%, with forsterite composition [100× $\left(\mathrm{Mg} /\left(\mathrm{Mg}+\mathrm{Fe}^{2+}\right)\right]$ ranging from 89 to 90.5 (Table 1). The spinel content varies from (about)
0.5 to 1.5 vol.\% having relatively low $\mathrm{Cr}-$ number $(\mathrm{Cr} / \mathrm{Cr}+\mathrm{Al})$, about 8.5 (Table 1$)$. Having low Cr-number (e.g. high $\mathrm{Al}_{2} \mathrm{O}_{3}$ content) and relatively high forsterite component, Nghia Dan mantle xenoliths plot in the field of (intraplate) oceanic hotspot peridotites believed to be fertile and enriched for experiencing low degrees of partial melting as compared to peridotite residues in the ocean ridges, arc settings or ancient cratons (Figure 5, after Arai, 1994).

\subsubsection{Orthopyroxene}

The orthopyroxene content in Nghia Dan mantle xenoliths ranges from 19 to 25 vol.\% (Figure 3). The mineral is an enstatite showing a compositional range of $\mathrm{En}_{88.2-88.7} \mathrm{Fs}_{5.5-}$ ${ }_{6.4} \mathrm{Wo}_{1.3-1.4}$. The Mg-number varies in a narrow range, from 89.3 to 90 , about the range of coexisting olivine. The $\mathrm{Cr}_{2} \mathrm{O}_{3}$ contents are low, from 0.27 to 0.33 wt. $\%$. The $\mathrm{Cr}_{2} \mathrm{O}_{3}$ increase 
with increasing $\mathrm{Al}_{2} \mathrm{O}_{3}$, from 4.68 to 5.1wt.\%. The variation of $\mathrm{Cr}_{2} \mathrm{O}_{3}, \mathrm{Al}_{2} \mathrm{O}_{3}$ and $\mathrm{TiO}_{2}$ concentrations (from 0.12 to 0.22 wt.\%) may be small to notice the change in their corresponding Mg-number (Table 1).

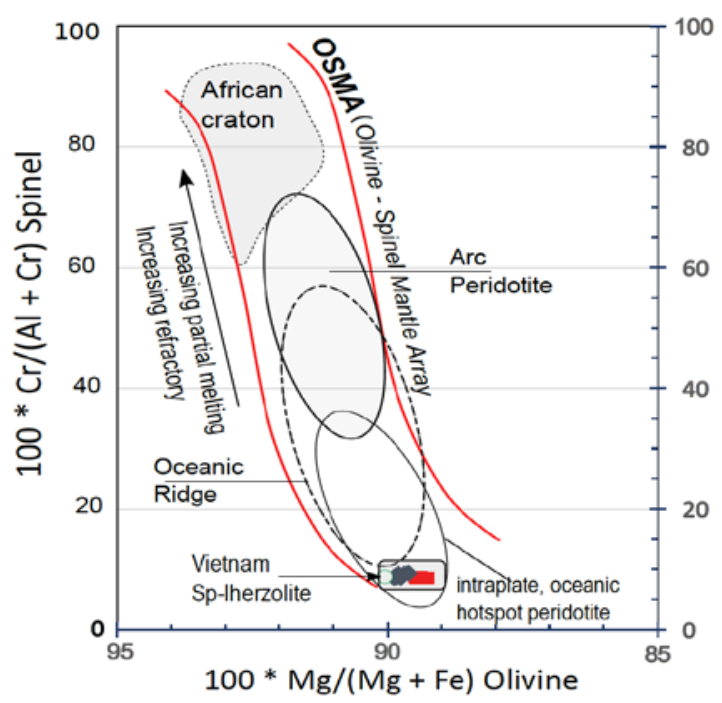

Figure 5. Olivine - Spinel Mantle Array (OSMA) showing distribution fields of peridotites from various tectonic settings. Residual peridotites produced by high degrees of partial melting are refractory (and depleted), having high $\mathrm{Cr}-$ numbers and forsterite contents. Redrawn after Arai (1994), data for oceanic ridges and intraplate oceanic hotspots are from Choi et al. (2005), Workman and Hart (2005) and Warren (2016)

\subsubsection{Clinopyroxene}

The clinopyroxene is a diopside which constitutes 3 to 5 vol.\%, in some rare cases up to $8-10$ vol.\% among the spinel lherzoliteforming minerals, showing a range of chemical compositions of $\mathrm{En}_{47.9-48.9} \mathrm{Fs}_{5.2-6.1} \mathrm{Wo}_{45.1-46.1}$. The Mg-number increases with increasing enstatite component, from 88.9 to 90.4. The $\mathrm{TiO}_{2}$ and $\mathrm{Cr}_{2} \mathrm{O}_{3}$ contents are moderate, from 0.6 to 0.7 wt.\%, and from 0.65 to 0.74 wt.\%, respectively. The $\mathrm{Al}_{2} \mathrm{O}_{3}$ concentrations vary from 7.1 to $7.5 \mathrm{wt} . \%$, which are slightly higher as compared with those in Jeju mantle spinel- lherzolite and elsewhere in East Asia (Choi et al., 2001, 2008). Despite minor differences in geochemical composition, the
Nghia Dan clinopyroxene is very much similar to clinopyroxene in mantle xenoliths in Cenozoic alkaline basalts in east and northeast China (Tatsumoto et al., 1992, Qi et al., 1995), the Japan Sea (Choi et al., 2001, 2008), and elsewhere in the Western Highlands, south-Central Vietnam, and southeastern continental shelf of East Vietnam Sea (Gorshkov, 1981; Fedorov and Koloskov, 2005; Malinovsky and Rashidov, 2015). The Nghia Dan mantle xenolith separated clinopyroxenes, however, have slightly higher wollastonite $\left(\mathrm{Ca}_{2} \mathrm{Si}_{2} \mathrm{O}_{6}\right)$ and (clino)- ferrosilite $\left(\mathrm{Fe}_{2} \mathrm{Si}_{2} \mathrm{O}_{6}\right)$ components, shifting more toward the hedenbergite field as compared to clinopyroxenes separated from mantle xenoliths in the (mid-) ocean ridges (after Johnson et al., 1990; Workman and Hart, 2005; Warren, 2016). $\mathrm{Al}_{2} \mathrm{O}_{3}$ and $\mathrm{TiO}_{2}$ concentrations in Nghia Dan orthopyroxene and clinopyroxene are higher as compared with mid-ocean ridge mantle xenolith separated clinopyroxene (e.g. Workman and Hart, 2005; Warren, 2016). Experimental data suggested that the higher $\mathrm{Al}_{2} \mathrm{O}_{3}$ content in pyroxenes the higher melting temperature and pressure of the minerals (Kushiro, 1996).

\subsection{Elemental geochemistry of Nghia Dan separated clinopyroxene}

The trace element compositions of Nghia Dan clinopyroxene are given in Table 2 . The data are normalized to the primitive mantle value (after Sun and McDonough, 1989), illustrated in Figure 6. Data of mantle xenolith separated clinopyroxenes from $1 \mathrm{Ma}$ alkaline basalt in the Dat Do district (Ba Ria-Vung Tau) (Hoang unpublished data) are plotted for reference. The trace element distribution pattern of Nghia Dan clinopyroxene is relatively smooth, showing a gradual decrease from heavy, less mobile elements to lighter, highly incompatible elements. The observation suggests that the Nghia Dan mantle xenoliths may have experienced small melting degrees, and that, other than the effect of melting and 
crystallization, Nghia Dan mantle peridotite residues may not undergo any significant post-melting process, such as melt addition or removal (as compared to, for example, the mantle xenolith in Dat Do alkaline basalt). In summary, the trace element distribution pattern of Nghia Dan clinopyroxene reflects typical geochemical characteristics of clinopyroxenes in alkaline basalt-borne mantle xenoliths (e.g. Embey-Isztin et al., 2001).

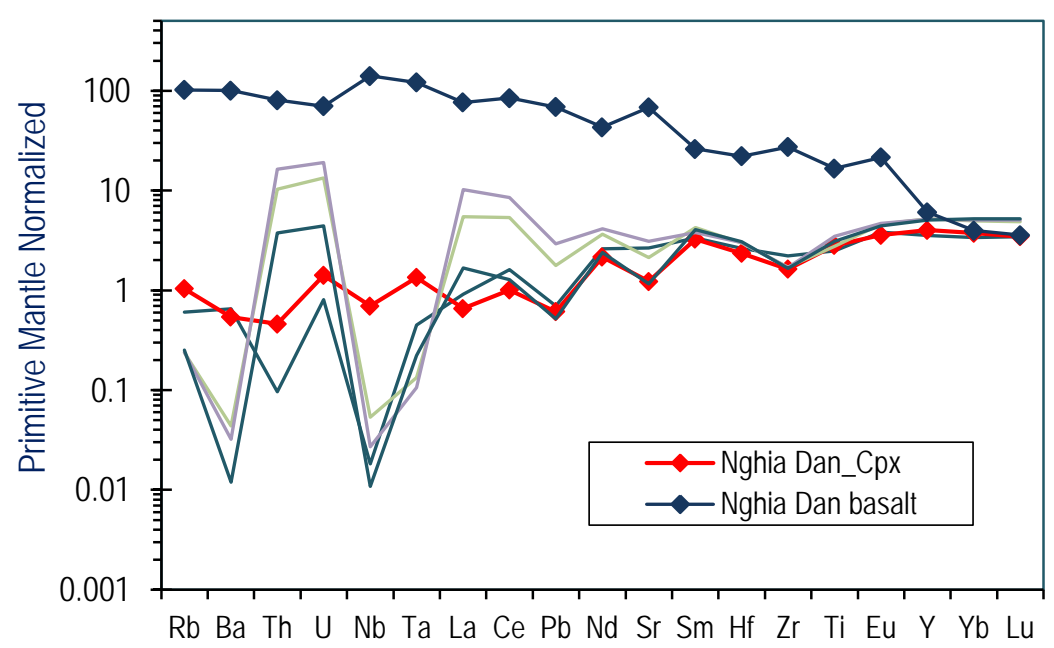

Figure 6. Trace element primitive mantle normalization of Nghia Dan clinopyroxene separate showing relatively smooth trend from moderately immobile to highly mobile elements (normalizing data are after Sun and McDonough, 1989). Shown are data for the host alkaline basalt and mantle xenolith- separated clinopyroxenes from Dat Do (Ba Ria - Vung Tau) for comparison. See text for details

\subsection{Isotope geochemistry of Nghia Dan mantle xenolith separated clinopyroxene}

The ${ }^{87} \mathrm{Sr} /{ }^{86} \mathrm{Sr}$ ratios vary from 0.70249 to 0.70269 , and ${ }^{143} \mathrm{Nd} /{ }^{144} \mathrm{Nd}$ range from 0.51322 0.51329 (Table 2). They plot in the depleted mantle field (DMM) along with several other Vietnamese separated clinopyroxenes, although most of the latter are more enriched than the Nghia Dan clinopyroxenes and plotting in the field of oceanic island basalts (Figure 7). In general, most (if not all) of the mantle xenolith separated clinopyroxenes in Vietnam are isotopically depleted and plot in the upper corner of the depleted quadrant differentiating from their host-basalts, suggesting that they are not genetically related. However, the isotope trending between depleted (e.g. NMORB: mid-ocean ridge basalt) and enriched mantle (EM1, EM2) may suggest possible interaction of depleted mantle-derived melts with enriched sources in the lithospheric mantle (Figure 7). The isotopic characteristics of Nghia Dan mantle xenolith separated clinopyroxenes (and elsewhere in Vietnam) are mostly similar to clinopyroxenes separated from mantle xenoliths in alkaline basalts in northeast China (Tatsumoto et al., 1992) and Jeju island (Choi et al., 2005, 2008).

In summary, the elemental and radiogenic isotopic characteristics of the mantle xenolith and their host alkaline basalt are vastly different, implying, most certainly, that they are not genetically related. Moreover, thermal contacts between host basalt and mantle xenolith are commonly observed, suggesting that the mantle xenolith is brought to the surface by alkaline basaltic melt formed at deeper levels. 
The basaltic melt must move up at a speed that is fast enough to tear off the mantle xenolith from its bed in the lithospheric mantle to bring to the surface (see Nixon (Editor), 1987; Qi et al., 1995; Choi et al., 2001; EmbeyIsztin et al., 2001).

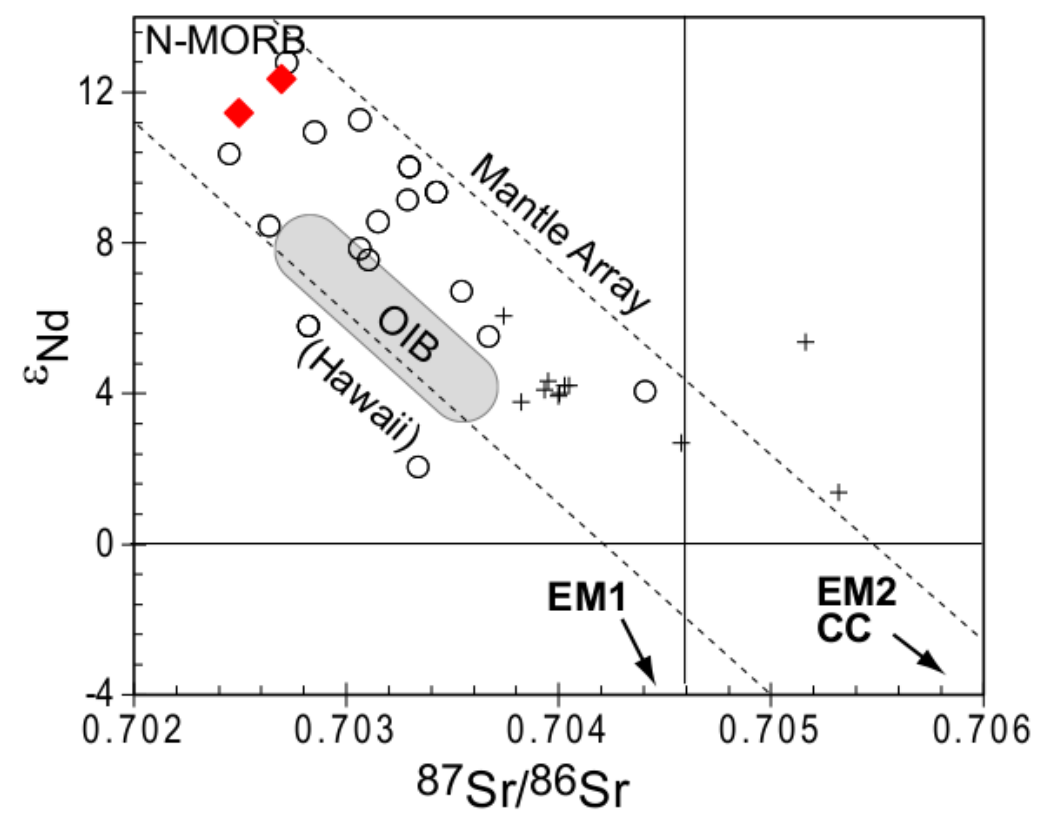

Figure 7. Plots of ${ }^{87} \mathrm{Sr} /{ }^{86} \mathrm{Sr}$ versus $\left.\varepsilon_{\mathrm{Nd}}\left[=\left({ }^{143} \mathrm{Nd} /{ }^{144} \mathrm{Nd}_{\mathrm{m}} / 0.512638\right)-1\right) \times 10000\right]$ of Vietnam alkaline basalt-borne mantle xenolith separated clinopyroxenes (empty circles; Hoang unpublished data) including Nghia Dan (red filled diamond) (Table 2) and host basalts (cross). Shown are fields of Depleted Mid-Ocean Ridge Basalt Mantle (N-MORB), Enriched Mantle type 1 and 2 (EM1 and EM2) (after Zindler and Hart, 1986); field of continental crust (CC) (after Taylor and McLennan, 1981) and Oceanic Island basalt (OIB Hawaii, after Norman and Garcia, 1999) for reference

\section{Discussion}

\subsection{Mantle peridotite melting}

Compiled data of mantle peridotites from oceanic ridges and other tectonic settings worldwide showed that an upper mantle peridotite is averagely composed of (in vol.\%) olivine (Ol: 57), orthopyroxene (Opx: 28), clinopyroxene (Cpx: 13) and spinel (Sp: 2). Partial melting of a peridotite having the above mentioned mineral assemblage to produce basaltic melt, according to a number of recent experimental studies (e.g. Takahashi and $\mathrm{Ku}-$ shiro, 1983; Takahashi, 1986; Johnson et al., 1990; Hirose and Kushiro, 1993; Kushiro, 1996, 1998), would occur in the following proportion (in vol.\%) Ol: 10, Opx: 20, Cpx:
68, and Sp: 2. Moreover, the melting process is fractional rather than batch melting (Johnson et al., 1990).

Basic fractional melting equation to show the change in concentration of an element in clinopyroxene with melting was developed by Gast (1968) and Shaw (1970) as follows:

$$
\frac{C_{s}^{i}}{C_{0}^{i}}=\left(\frac{1}{(1-F)}\right)\left(1-\frac{P F}{D_{0}^{i}}\right)^{1 / p}
$$

Where $C_{s}^{i}$ is the concentration of element $i$ in the residue (s) as a function of partial melting degree $(F) . C_{0}{ }^{i}$ is initial concentration of element $i$ and $D_{0}{ }^{i}$ is bulk solid partition coefficient of element $i$. $P$ weighted partition coefficient of liquid:

$$
\begin{aligned}
& \mathrm{P}=\Sigma p_{a} D_{a}^{i}=p_{\text {oliv }} D_{\text {oliv }}^{i}+p_{\text {opx }} D_{\text {opx }}^{i}+ \\
& p_{\text {cpx }} D_{\text {cpx }}^{i}+p_{\text {spin }} D_{\text {spin }}^{i}
\end{aligned}
$$


$D_{\alpha}{ }^{i}$ : partition coefficient of element $\mathrm{i}$ in $\alpha$ mineral phase;

$p_{\alpha}$ : proportion of mineral phase entering liquid.

Because the bulk trace element abundance of upper mantle peridotite is mainly incorporated in clinopyroxene, Equation (1) therefore may be changed to (3) (e.g. Johnson et al., 1990):

$$
\frac{C_{c p x}^{i}}{C_{0, c p x}^{i}}=\left(1-\frac{P F}{D_{0}^{i}}\right)^{\left(\frac{1}{p}-1\right)}
$$

To apply equation (4) it needs to change bulk rock variable to clinopyroxene as follows:

$$
\begin{aligned}
& C_{\text {bulk }}^{i}=C_{c p x}^{i}\left(\frac{D_{\text {bulk }}}{D_{c p x}}\right) \\
& D_{\text {bulk }}=\sum x_{\alpha} D_{\alpha}^{i}=x_{\text {oliv }} D_{\text {oliv }}^{i}+x_{\text {opx }} D_{\text {opx }}^{i}+x_{c p x} D_{c p x}^{i}+ \\
& x_{\text {spin }} D_{\text {spin }}^{i}
\end{aligned}
$$

Where $\mathrm{x}_{\alpha}$ is weight fraction of mineral phase.

Using equations 4 and 5 , the trace element abundance of a peridotite can be interpolated from the trace element concentrations in clinopyroxene separated from the peridotite.
Applying equation 5 to the trace element concentration of Nghia Dan separated clinopyroxene (Table 2), trace element abundance of parental mantle peridotites can be determined. Depending on the bulk partition coefficient of elements in individual rock-forming minerals (Table 3 ), their constituents in a given peridotite and proportion of mineral entering the liquid (Table 4), and the melting degrees, the interpolated trace element abundances may be differently acquired. The computed data are shown in Table 4 and illustrat-

\begin{tabular}{|c|c|c|c|c|}
\hline & $\mathrm{Ol}$ & Opx & Cpx & Sp \\
\hline $\mathrm{La}$ & 0.0002 & 0.026 & 1.414 & 0.016 \\
\hline $\mathrm{Ce}$ & 0.0005 & 0.137 & 3.930 & 0.027 \\
\hline $\operatorname{Pr}$ & 0.0002 & 0.034 & 0.744 & 0.003 \\
\hline $\mathrm{Nd}$ & 0.002 & 0.194 & 4.044 & 0.013 \\
\hline Sm & 0.004 & 0.109 & 1.585 & 0.003 \\
\hline $\mathrm{Eu}$ & 0.002 & 0.056 & 0.611 & 0.001 \\
\hline Gd & 0.007 & 0.239 & 2.209 & 0.004 \\
\hline $\mathrm{Tb}$ & 0.003 & 0.051 & 0.415 & 0.001 \\
\hline Dy & 0.026 & 0.396 & 2.916 & 0.010 \\
\hline Но & 0.010 & 0.096 & 0.633 & 0.003 \\
\hline $\mathrm{Er}$ & 0.036 & 0.363 & 1.735 & 0.012 \\
\hline $\mathrm{Yb}$ & 0.086 & 0.376 & 1.615 & 0.017 \\
\hline $\mathrm{Lu}$ & 0.016 & 0.065 & 0.235 & 0.003 \\
\hline
\end{tabular}
ed in Figures 8a, b.

Table 3. Elemental liquid/solid partition coefficients $\left(D_{\text {solid }}^{\text {liquid }}\right)$ for rock-forming minerals of mantle peridotite

\begin{tabular}{|c|c|c|c|c|c|}
\hline Sample ID & ND-MX-1 & ND-MX-2 & ND-MX-3 & ND-MX-4 & ND-MX-5 \\
\hline $\mathrm{OL}$ & 77.40 & 74.70 & 70.94 & 71.06 & 69.60 \\
\hline $\mathrm{CPX}$ & 2.96 & 4.27 & 3.31 & 5.51 & 4.32 \\
\hline OPX & 18.90 & 20.10 & 25.37 & 22.72 & 24.50 \\
\hline SP & 0.73 & 1.00 & 0.37 & 0.71 & 1.66 \\
\hline La (ppm) & 0.055 & 0.078 & 0.062 & 0.099 & 0.079 \\
\hline $\mathrm{Ce}$ & 0.097 & 0.133 & 0.113 & 0.169 & 0.139 \\
\hline $\operatorname{Pr}$ & 0.133 & 0.185 & 0.152 & 0.235 & 0.191 \\
\hline $\mathrm{Nd}$ & 0.203 & 0.279 & 0.234 & 0.354 & 0.290 \\
\hline $\mathrm{Sm}$ & 0.343 & 0.460 & 0.400 & 0.577 & 0.483 \\
\hline $\mathrm{Eu}$ & 0.394 & 0.522 & 0.463 & 0.652 & 0.552 \\
\hline Gd & 0.401 & 0.524 & 0.474 & 0.649 & 0.556 \\
\hline $\mathrm{Tb}$ & 0.504 & 0.647 & 0.596 & 0.795 & 0.691 \\
\hline Dy & 0.574 & 0.724 & 0.681 & 0.882 & 0.776 \\
\hline Ho & 0.627 & 0.777 & 0.744 & 0.937 & 0.836 \\
\hline Er & 0.714 & 0.869 & 0.845 & 1.038 & 0.938 \\
\hline $\mathrm{Tm}$ & 0.675 & 0.821 & 0.798 & 0.980 & 0.887 \\
\hline $\mathrm{Yb}$ & 0.787 & 0.928 & 0.923 & 1.085 & 1.002 \\
\hline $\mathrm{Lu}$ & 0.803 & 0.934 & 0.937 & 1.082 & 1.007 \\
\hline
\end{tabular}

Table 4. Mineral modal constituents of Nghia Dan alkaline basalt-bearing mantle xenoliths and rare earth element concentrations estimated for related mantle xenolith whole rock 

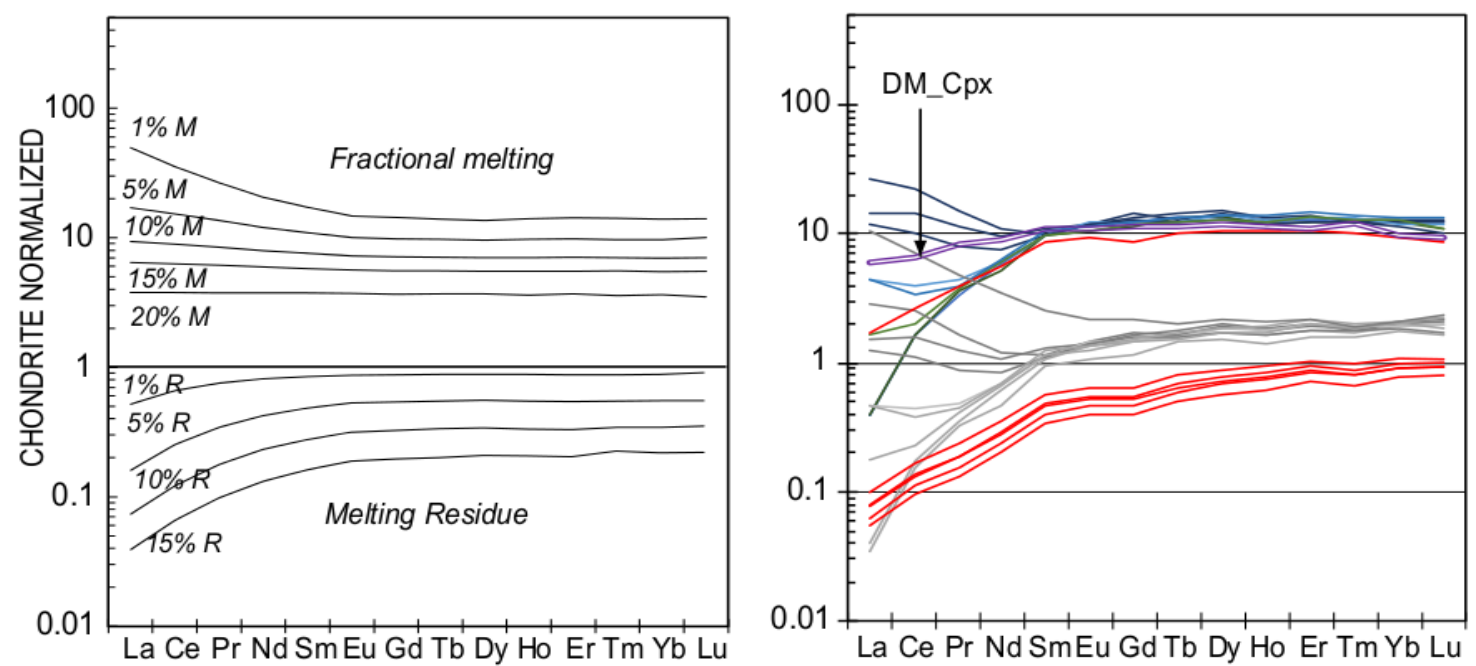

Figure 8a, b. Chondrite normalized computed rare earth element abundance produced by fractional melting (Eq. 1); A\%M and A\%R: rare earth element composition of melt $(\mathrm{M})$ or residue $(\mathrm{R})$ produced by A melting degree (8a, left); rare earth element chondrite normalized distribution pattern of Nghia Dan clinopyroxene (thick, red line) and corresponding residual parental peridotite (thin, red lines) according to different mineral constituents (8b, right). Shown for comparison are clinopyroxene separate and their residual peridotite from Dat Do (Ba Ria- Vung Tau), and clinopyroxene (DM_Cpx) separated from the representative depleted mantle peridotite (Computing template is after Workman and Hart, 2005; Warren, 2016). Normalizing data are after Anders and Grevesse (1989)

By interpolation, the trace element contents of Nghia Dan clinopyroxene may be obtained by melting degree between 8 to $12 \%$ (Figures 8a, b) of a mantle peridotite which is relatively depleted (and refractory). The Nghia Dan clinopyroxene is more depleted in light rare earth element concentrations as compared to an average mid-ocean ridge peridotite separated clinopyroxene (DM-Cpx) (Figure 8b), suggesting that the Nghia Dan mantle xenolith may have experienced multiple melting events (Takahashi, 1986; Hirose and Kushiro, 1993). Note that clinopyroxenes separated from Dat Do mantle xenoliths (Ba Ria - Vung Tau) show strong geochemical heterogeneity, suggesting mantle peridotites in the lithospheric mantle may undergo various melting events and/or melt addition or removal (Carlson and Irving, 1994) (Figure 8b).

\subsection{Thermal state of the lithospheric mantle under Nghia Dan}

A number of geothermometers for applicable mineral assemblages of mantle peridotite xenoliths have been introduced over the years. Equilibrium temperatures may be estimated using geothermometers based on (1) enstatite component of coexisting two pyroxenes (Wells, 1977; Brey and Kohler, 1990), (2) Alsolubility in orthopyroxene coexisting with olivine and spinel (Sachtleben and Seck, 1981; Webb and Wood, 1986); (3) ${\mathrm{Mg}-\mathrm{Fe}^{2+}}^{2}$ exchange between olivine and spinel (Ballhaus et al., 1991); (4) concentration of Group II elements ( $\mathrm{Cr}, \mathrm{Al}, \mathrm{Sc}, \mathrm{Ca}$ and $\mathrm{Na}$ ) in mantle peridotite olivine (De Hoog et al., 2010). Brey and Köhler (1990), following many testing combinations of geothermobarometers, suggested that the geobarothermometer of Köhler and Brey (1990) may provide a reasonable T$\mathrm{P}$ estimate for spinel peridotite.

Experimentally, Putirka et al. (1996), followed by Putirka et al. (2003) developed equations (1) and (2) two-pyroxene pressure and temperature estimates. Equation (2) has been improved from a previous equation by Putirka (2008, 2017).

$P($ kbar $)=$

$-88.3+2.82 \times 10^{-3} T(K) \ln \left[\left[J d^{c p x}\right] /\right.$ 
$\left[\mathrm{Na}^{\mathrm{liq}} \mathrm{Al}^{\mathrm{liq}}\left(\mathrm{Si}^{\mathrm{liq}}\right)^{2}\right]+2.19 \times 10^{-2} \mathrm{~T}\left({ }^{\circ} \mathrm{K}\right)-$

$25.1 \ln \left[\mathrm{Ca}^{l i q} \mathrm{Si}^{\mathrm{liq}}\right]+7.03\left[\mathrm{Mg}^{\prime l i q}\right]+$

$12.41 \ln \left[\mathrm{Ca}^{\mathrm{liq}}\right]$

$P($ kbar $)=$

$-26.3+$

$39.2 \times 10^{-4} T(K)\left[\frac{X_{J d}^{c p x}}{\left(X_{N a}^{l i q}\right)\left(X_{A l O 1.5}^{l i q}\right)\left(X_{S i O 2}^{l i q}\right)^{2}}\right]-$

$4.22 \ln \left[X_{D i H d}^{c p x}\right]+78.4\left[X_{\text {AlO1.5 }}^{l i q}\right]+$

$394\left[X_{\text {NaO0.5 }}^{l i q}+X_{K O 0.5}^{l i q}\right]^{2}$

The temperature is in Kelvin, pressure is in kbar, $J d^{c p x}$ is molecule component of jadeite in clinopyroxene, number of cations in pyroxene are calculated based on 6 oxygen atoms. $D i H d^{c p x}$ is molecule component of diopside and hedenbergite in clinopyroxene. $A l^{l i q}$ is $\mathrm{AlO}_{1.5}$ cation content in melts, $\mathrm{MgO}{ }^{\text {,liq }}$ is cation content of $\mathrm{MgO}^{\mathrm{liq}} /\left(\mathrm{MgO}^{\mathrm{liq}}+\mathrm{Fe}^{\mathrm{liq}}\right)$. See Putirka et al. (1996, 2003) and Putirka (2008) for more details.

The computed pressure and temperature of mineral assemblages in Nghia Dan mantle peridotites basing on coexisting pyroxenes using equations (1) and (2) (Putirka et al., 1996, 2003; Putirka, 2008, 2017) are shown in Table 5 . The estimated data are compared with the temperatures calculated using approaches by Wells (1977) and Brey and Köhler (1990). The temperatures estimated for coexisting pyroxenes in Nghia Dan mantle xenoliths using equations of Putirka et al. $(1996,2003)$ and Putirka $(2008,2017)$ are about $30^{\circ} \mathrm{C}$ lower as compared to those using equations of Wells (1977), Brey and Kohler (1990) and De Hoog et al. (2009) (Figure 9).

Table 5. Two-pyroxene temperature - pressure estimates and observed $\mathrm{K}_{\mathrm{D}}{ }^{(\mathrm{Fe}-\mathrm{Mg})}$ values for Nghia Dan mantle xenoliths (computed after Putirka, 2008). Shown for comparison are two-pyroxene crystallization temperatures by Brey and Kohler (1990) method

\begin{tabular}{|c|c|c|c|c|}
\hline \multirow[b]{2}{*}{ Sample ID } & \multicolumn{2}{|c|}{ Putirka (2008) (*) } & \multirow{2}{*}{$\mathrm{K}_{\mathrm{D}}{ }^{(\mathrm{Fe}-\mathrm{Mg})}$} & \multirow{2}{*}{$\begin{array}{c}\text { Brey \& Kohler } \\
(1990) \mathrm{T}^{\circ} \mathrm{C}\end{array}$} \\
\hline & $\mathrm{T}^{\circ}(\mathrm{C})$ & $\mathrm{P}$ (kbar) & & \\
\hline B040313-16Сpх/1 & 1023.5 & 13.1 & 1.053 & 1079.1 \\
\hline В040313-16Сpx/2 & 1029.3 & 13.9 & 1.053 & 1081.0 \\
\hline В040313-16Срх/3 & 1011.3 & 13.4 & 0.948 & 1051.7 \\
\hline B040313-16Сpx/4 & 1023.9 & 13.6 & 1.014 & 1076.9 \\
\hline В040313-16Срх/5 & 1034.4 & 14.1 & 1.070 & 1067.7 \\
\hline А040313-7Срх/1 & 1016.9 & 14.1 & 0.927 & 1072.9 \\
\hline A040313-7Сpх/2 & 1037.1 & 13.6 & 1.051 & 1051.3 \\
\hline A040313-7Cрх/3 & 1009.0 & 13.8 & 1.050 & 1048.0 \\
\hline A040313-7Сpx/4 & 1043.6 & 14.1 & 1.121 & 1076.7 \\
\hline A040313-7Cpx/5 & 1027.2 & 14.2 & 1.050 & 1071.2 \\
\hline
\end{tabular}

(*) www.minsocam.org/MSA/RIM/RiMG069/RiMG069_Ch03_two-pyroxene_P-T.xls

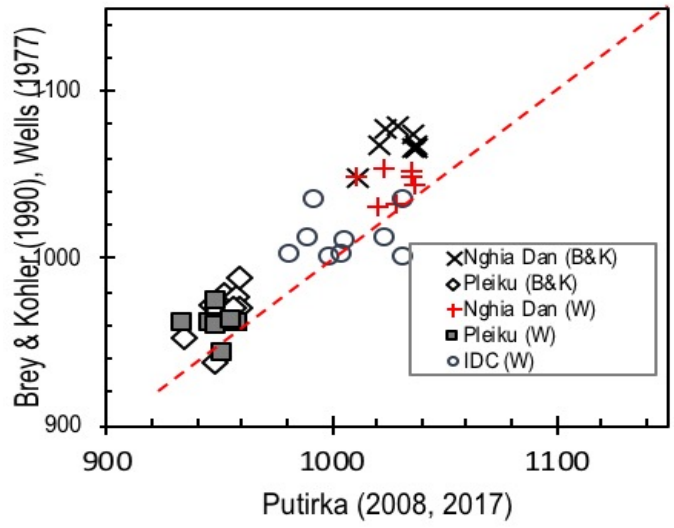

$\leftarrow$ Figure 9. Plots of temperature estimates for equilibrium two-pyroxenes in Nghia Dan mantle xenoliths using geothermometers of Wells (1977), Brey and Kohler (1990) versus Putirka (2008, 2017). Data for Pleiku (Western Highlands) and Tro Islet (Ile des Cendres, East Vietnam Sea) mantle xenoliths (Hoang unpublished data) are shown for reference

\subsection{Geotherm beneath Western Nghe An}

Cenozoic basaltic volcanism in the Western Highlands of Vietnam was driven by the regional thermally anomalous mantle fol- 
lowed by lithospheric extension (e.g. Garnier et al., 2005; Izokh et al., 2010, and references therein). Using primitive melt compositions computed for Cenozoic basalts from the Western Highlands, and elsewhere in the offshore and coastal areas of Vietnam to interpolate melting temperatures and pressures of the basalts by correlating with experimental mantle peridotite melting data (e.g. Takahashi and Kushiro, 1983; Kushiro, 1990, 1996, 1998; Hirose and Kushiro, 1993) Hoang et al. (2014) reported that mantle beneath Vietnam is hotter than normal (e.g. $1280^{\circ} \mathrm{C}$ ), reaching up to $1380^{\circ} \mathrm{C}$. The thermally anomalous mantle has been viewed as a consequence of the India- Eurasian collision that led to the Tethys closure, uplift of Himalaya and Tibet, subduction initiation under the Himalaya (Tapponnier et al., 1982, 1990), and collision-induced east-west mantle injection (Tamaki, 1995). The extrusion (injection) of deep, (thus) hot mantle flow to east and southeast Asia was the main cause of mantle perturbation and temperature upsurge, leading to mantle melting and wide-spread basaltic volcanism in the region regardless of the regional lithospheric extension factor is small (after Latin and White, 1990).

The crystallization temperature was estimated for various mineral assemblages in alkaline basalt-bearing spinel-lherzolites in the Western Highlands and Southeastern region of Vietnam using the geothermometer of De Hoog et al. (2009), showed a temperature range of $850-1150^{\circ} \mathrm{C}$ and pressure varying from 14 to 25 kbar (Hoang unpublished data). A geotherm constructed for Western Highlands, Southeastern region and Nghia Dan is shown in Figure 10, lying between two conductive geothermal lines in post- Phanerozoic continental lithosphere for heat flow of 80 to $90 \mathrm{~mW} / \mathrm{m}^{2}$, respectively (after Pollack and Chapman, 1977). The Nghia Dan geothermal gradient $\left(1020-1045^{\circ} \mathrm{C}\right.$ corresponding to pressure range of 13-14.2 kbar, Table 1) is higher than that of conductive model and even higher as compared with that of Western Highlands and Southeastern region of Vietnam (Figure 10), suggesting a perturbation of thermal structure in the lithospheric mantle under the relating region (e.g. Hoang et al., 2014).

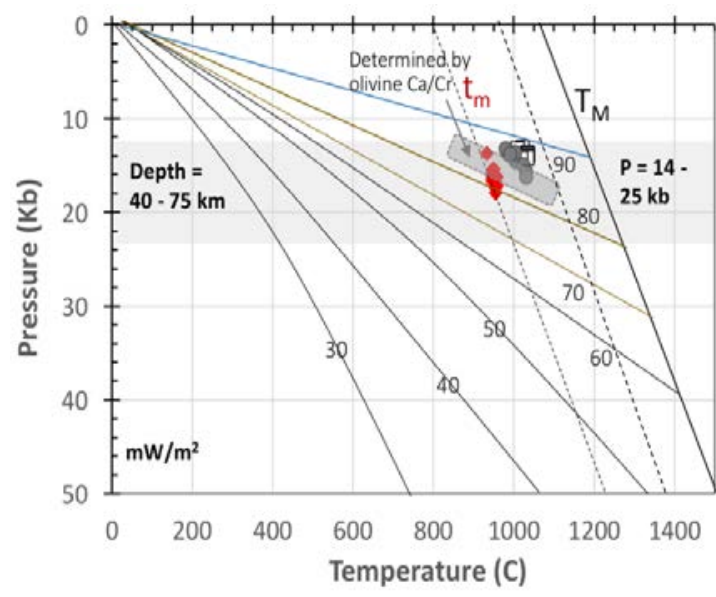

Figure 10. A geotherm for Nghia Dan determined by spinel lherzolite (thick dashed line) using two-pyroxene geothermobarometers by Putirka et al. $(1996,2003)$ and Putirka (2008, 2017). Thin solid lines are model conductive geotherms of continental areas with surface heat flows from 30 to $90 \mathrm{~mW} / \mathrm{m}^{2}$ (Pollack and Chapman, 1977). Thin dashed line $\left(t_{m}\right)$ thermally normal mantle adiabatic line $c a .1280^{\circ} \mathrm{C}$, Thick continuous line $\left(\mathrm{T}_{\mathrm{M}}\right)$ continuous line, elevated temperature adiabatic, ca. $>1380^{\circ} \mathrm{C}$ (Hoang unpublished. Shown for comparison are mantle xenoliths from Pleiku: red filled diamonds, Tro islet (Ile des Cendres): white filled square (Malinovsky and Rashidov, 2015), Western Highlands and Southeastern region of Vietnam: filled rectangle (Hoang unpublished data)

\subsection{Lithospheric mantle dynamics under Western Nghe An}

Any process causing isotope disequilibrium, for example, melt extraction, source mixing or crustal assimilation to the isotopic systems such as Sm-Nd, Lu-Hf, Rb-Sr... can be traceable and determined, especially for the systems that are durable to secondary alteration such as Sm-Nd and Lu-Hf (Carlson and Lugmair, 1979, 1981; DePaolo and Wasserburg, 1976; DePaolo, 1981). 
Determination of Sm-Nd model age for alkaline basalt-borne mantle xenolith is one of the ways to understand geodynamic processes causing isotope disequilibrium to the isotopic system before the xenolith being brought to the surface. Suppose the lithospheric mantle was formed about $3 \mathrm{Ga}$ following the mantle melting to form the crust. Any major geodynamic event having occurred in the lithospheric mantle after the $3 \mathrm{Ga}$ time causing isotopic perturbation and changing the evolutional trend of the isotopic system may be determined using basic isotopic parent-daughter relationship (see footnote in Table 2). The model age for Nghia Dan spinel lherzolites varies between 122 and 127 million years (Table 2). Assuming the computed the age could be significant, it would mean that there was a major geodynamic event having occurred in the lithospheric mantle in the midEarly Cretaceous (Aptian).

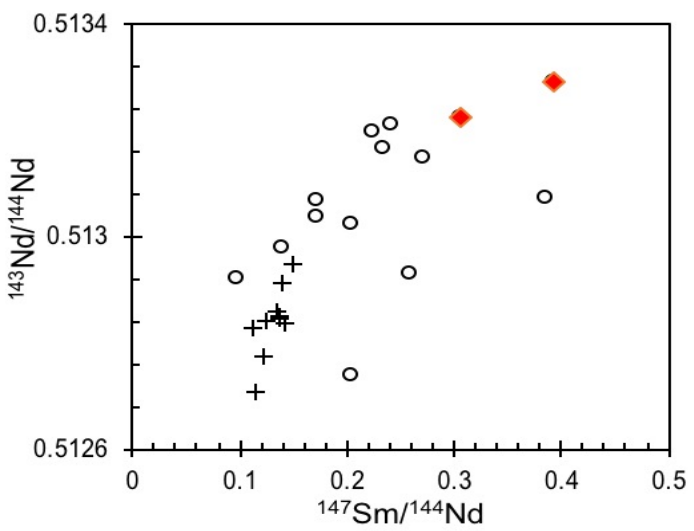

Figure 11. Plots of ${ }^{143} \mathrm{Sm} /{ }^{144} \mathrm{Nd}$ vs. ${ }^{143} \mathrm{Nd} /{ }^{144} \mathrm{Nd}$ of Nghia Dan spinel lherzolite separated clinopyroxene (red filled diamond); shown for reference are clinopyroxene separated from mantle xenoliths collected in the Western Highlands (Pham Tich Xuan, personal communication). Host basalts (cross) are shown for comparison

\section{Conclusions}

From the above descriptions the following conclusions may be drawn:

The mantle xenoliths in Pliocene alkaline basalts in Nghia Dan (West Nghe An) are ge- ochemically depleted spinel lherzolites. They are residual entities of mantle peridotite melting from 8 to $12 \%$ that became basic components of the lithospheric mantle before being brought to the surface by basaltic melt.

Temperature and pressure estimates for mineral assemblages in Nghia Dan mantle xenoliths by various geothermobarometers vary from 1020 to $1050^{\circ} \mathrm{C}$ and 13 to $14.2 \mathrm{kbar}$ (ca. 40 to $43 \mathrm{~km}$ ), having much higher geothermal gradient as compared to that of the conductive model. This observation is supported by previous studies of mantle thermal state under Western Highland and elsewhere in Vietnam that the mantle in the region is anomalously higher than normal by 50 to $100^{\circ} \mathrm{C}$.

Sm-Nd model age calculated for Nghia Dan mantle xenolith separated clinopyroxene yielded 127 and 122 Ma (mid-Early Cretaceous). Assuming the model age is meaningful there would be a major geodynamic event having occurred under Western Nghe An during this period, large enough to cause perturbation in the Sm-Nd isotopic system.

\section{Acknowledgments}

This report was conducted under thematic study entitled "Study of elemental and isotopic geochemistry of mantle xenolith in alkaline basalt in Nghia Dan (Nghe An) with implications to lithospheric mantle characteristics under the region" funded by Vietnam Academy of Science and Technology to TTH for the year 2017. The support is gratefully acknowledged. Comments by two anonymous reviewers that helped improve the quality of the report from an earlier version are appreciated.

\section{References}

An A-R., Choi S.H., Yu Y-g., Lee D-C., 2017. Petrogenesis of Late Cenozoic basaltic rocks from southern Vietnam. Lithos, 272-273 (2017), 192-204.

Anders E., Grevesse N., 1989. Abundances of the elements: meteorite and solar. Geochimica et Cosmochimica Acta, 53, 197-214. 


\section{Tran Thi Huong and Nguyen Hoang/Vietnam Journal of Earth Sciences 40 (2018)}

Anderson D.L, 1994. The subcontinental mantle as the source of continental flood basalts; the case against the continental lithosphere mantle and plume hear reservoirs. Earth and Planetary Science Letter, 123, 269-280.

Arai S., 1994. Characterization of spinel peridotites by olivine-spinel compositional relationships: review and interpretation. Chemical Geology, 113, 191-204.

Ballhaus C., Berry R.G., Green D.H., 1991. High pressure experimental calibration of the olivine orthopyroxene-spinel oxygen geobarometer: implications for the oxidation state of the upper mantle. Contributions to Mineralogy and Petrology, 107, 27-40.

Barr S.M. and MacDonald A.S., 1981. Geochemistry and geochronology of late Cenozoic basalts of southeast Asia: summary. Geological Society of America Bulletin, 92, 508-512.

Brey G.P., Köhler T., 1990. Geothermobarometry in four-phase lherzolite II. New thermobarometers, and practical assessment of existing thermobarometers. Journal of Petrology, 31, 1353-1378.

Briais A., Patriat P., Tapponnier P., 1993. Updated interpretation of magnetic anomalies and seafloor spreading stages in the South China Sea, implications for the Tertiary tectonics of SE Asia. Journal of Geophysical Research, 98, 6299-6328.

Carlson R.W., Irving A.J., 1994. Depletion and enrichment history of subcontinental lithospheric mantle: an $\mathrm{Os}, \mathrm{Sr}, \mathrm{Nd}$ and $\mathrm{Pb}$ isotopic study of ultramafic xenoliths from the northwestern Wyoming Craton. Earth and Planetary Science Letters, 126, 457-472.

Carlson R.W., Lugmair G.W., 1979. Sm-Nd constraints on early lunar differentiation and the evolution of KREEP. Earth and Planetary Science Letters, 45, 123-132.

Carlson R.W., Lugmair G.W., 1981. Sm-Nd age of lherzolite 67667: implications for the processes involved in lunar crustal formation. Earth and Planetary Science Letters, 56, 1-8.

Choi H.S., Mukasa S.B., Zhou X-H., Xian X-G.H., Andronikov A.V., 2008. Mantle dynamics beneath East Asia constrained by $\mathrm{Sr}, \mathrm{Nd}, \mathrm{Pb}$ and $\mathrm{Hf}$ isotopic systematics of ultramafic xenoliths and their host basalts from Hannuoba, North China. Chemical Geology, 248, 40-61.
Choi S.H., Jwa Y.-J., Lee H.Y., 2001. Geothermal gradient of the upper mantle beneath Jeju Island, Korea: evidence from mantle xenoliths. Island Arc, 10, 175-193.

Choi S.H., Kwon S-T., Mukasa S.B., Sagon H., 2005. $\mathrm{Sr}-\mathrm{Nd}-\mathrm{Pb}$ isotope and trace element systematics of mantle xenoliths from Late Cenozoic alkaline lavas, South Korea. Chemical Geology, 22, 40-64.

Cox K.G., Bell J.D., Pankhurst R.J., 1979. The Interpretation of Igneous Rocks. George Allen \& Unwin.

Cung Thuong Chi, Dorobek S.L., Richter C., Flower M., Kikawa E., Nguyen Y.T., McCabe R., 1998. Paleomagnetism of Late Neogene basalts in Vietnam and Thailand: Implications for the Post-Miocene tectonic history of Indochina. In: Flower M.F.J., Chung, S.L., Lo, C.H., (Eds.). Mantle Dynamics and Plate Interactions in East Asia. Geodynamics Ser, American Geophysical Union, 27, 289-299.

De Hoog J.C.M., Gall L., Cornell D.H., 2010. Traceelement geochemistry of mantle olivine and application to mantle petrogenesis and geothermobarometry. Chemical Geology, 270, 196-215.

DePaolo D. J., 1981. Neodymium isotopes in the Colorado Front Range and crust - mantle evolution in the Proterozoic. Nature, 291, 193-197.

DePaolo D.J., Wasserburg G.J., 1976. Nd isotopic variations and petrogenetic models. Geophysical Research Letters, 3(5), 249-252. Doi: https://doi.org/10.2113/gselements.13.1.11.

Embey-Isztin A., Dobosi G., Meyer H.-P., 2001. Thermal evolution of the lithosphere beneath the western Pannonian Basin: evidence from deep-seat xenoliths. Tectonophysics, 331, 285-306.

Fedorov P.I., Koloskov A.V., 2005. Cenozoic volcanism of Southeast Asia. Petrologiya, 13(4), 289-420.

Frey F.A., Prinz M., 1978. Ultramafic inclusions from San Carlos, Arizona: Petrologic and geochemical data bearing on their Petrogenesis. Earth and Planetary Science Letters, 38, 129-176.

Garnier V., Ohmenstetter D., Giuliani G., Fallick A.E., Phan T.T., Hoang Q.V., Pham V.L., Schawarz D., 2005. Basalt petrology, zircon ages and sapphire genesis from Dak Nong, southern Vietnam. Mineralogical Magazine, 69(1), 21-38. 
Gast P.W., 1968. Trace element fractionation and the origin of tholeiitic and alkaline magma types. Geochimica et Cosmochimica Acta, 32, 1057-1086.

Gorshkov A.P, Ivanenko A.N., Rashidov V.A., 1984. Hydro-magnetic investigations of submarine volcanic zones in the marginal seas of Pacific Ocean (Novovineisky and Bien Dong seas). Pacific Ocean Geology, 1, 13-20.

Gorshkov A.P., 1981. Investigation of submarine volcanoes during the $10^{\text {th }}$ course of scientific research vessel 'Volcanolog'. Volcanology and Seismology, 6, 39-45 (in Russian).

Hart S.R., 1988. Heterogeneous mantle domains: signatures, genesis and mixing chronologies. Earth and Planetary Science Letters, 90, 273-296.

Hirose K., Kushiro I., 1993. Partial melting of dry peridotites at high pressures: determination of composition of melts segregated from peridotite using aggregate of diamond. Earth Planet Science Letters, 114, 477-489.

Hoang-Thi H.A., Choi S.H., Yongjae Yu Y-g., Pham T.H., Nguyen K.H., Ryu J-S., 2018. Geochemical constraints on the spatial distribution of recycled oceanic crust in the mantle source of late Cenozoic basalts, Vietnam. Lithos, 296-299 (2018), 382-395.

Izokh A.E., Smirnov S.Z., Egorova V.V., Tran T.A., Kovyazin S.V., Ngo T.P., Kalinina V.V., 2010. The conditions of formation of sapphire and zircon in the areas of alkali-basaltoid volcanism in Central Vietnam. Russian Geology and Geophysics, 51(7), 719-733.

Johnson K.T., Dick H.J.B. and Shimizu N., 1990. Melting in the oceanic upper mantle: An ion microprobe study of diopsides in abyssal peridotites. Journal of Geophysical Research (solid earth), 95, 2661-2678.

Kölher T.P., Brey G.P., 1990. Calcium exchange between olivine and clinopyroxene calibrated as a geothermobarometer for natural peridotites from 2 to 60 $\mathrm{kb}$ with applications. Geochimica et Cosmochimica Acta, 54(9), 2375-2388.

Kushiro I., 1996. Partial melting of a fertile mantle peridotite at high pressure: An experimental study using aggregates of diamond. In: A. Basu and S.R. Hart (Eds.), Earth Processes: Reading the Isotopic Code. AGU Monograph, 95, 109-122.
Kushiro I., 1998. Compositions of partial melts formed in mantle peridotites at high pressures and their relation to those of primitive MORB. Physics of Earth and Planetary Interiors, 107, 103-110.

Latin D., White N., 1990. Generating melt during lithospheric extension: Pure shear vs. simple shear. Geology, 18, 327-331.

Lee T.-y. and Lawver L., 1995. Cenozoic plate reconstruction of Southeast Asia. In: M.F.J. Flower, R.J. McCabe and T.W.C. Hilde (Editors), Southeast Asia Structure, Tectonics, and Magmatism. Tectonophysics, $85-138$.

Li C-F., et al., 2015. Seismic stratigraphy of the central South China Sea basin and implications for neotectonics. Journal of Geophysical Research (solid earth), 120, 1377-1399. Doi:10.1002/2014JB011686.

Li C.-F., et al., 2014. Ages and magnetic structures of the South China Sea constrained by deep tow magnetic surveys and IODP Expedition 349 Geochemistry, Geophysics, Geosystems, 14, 4958-4983.

Malinovsky A.I., Rashidov V.A., 2015. Compositional characteristics of sedimentary and volcanosedimentary rocks of Phu Quy-Catwick island group in the continental shelf of Vietnam. Bulletin of Kamchatka Regional Association of 'Educational Scientific’ Center, Earth Sciences, 27(3), 12-34 (in Russian with English summary).

McCulloch M.T., Wasserburg G.J., 1978. Sm-Nd and $\mathrm{Rb}-\mathrm{Sr}$ chronology of continental crust formation. Science, 200(4345), 1003-1011.

Menzies M.A., Arculus R.L., Best M.G., et al., 1987. A record of subduction process and within-plate volcanism in lithospheric xenoliths of the southwestern USA. In P.H. Nixon (Editor), Mantle Xenoliths, John Wiley \& Sons, Chichester, 59-74.

Nguyen Hoang, Ogasawara M., Tran Thi Huong, Phan Van Hung, Nguyen Thi Thu, Cu Sy Thang, Pham Thanh Dang, Pham Tich Xuan, 2014. Geochemistry of Neogene Basalts in the Nghia Dan district, western Nghe An. J. Sci. of the Earth, 36, 403 -412.

Nguyen Kinh Quoc, Nguyen Thu Giao, 1980. Cenozoic volcanic activity in Viet Nam. Geology and Mineral Resources, 2, 137-151 (in Vietnamese with English abstract). 
Nixon P.H., 1987 (Editor). Mantle xenoliths. John Wiley and Sons, 844p.

Norman M.D. and Garcia M.O., 1999. Primitive magmas and source characteristics of the Hawaiian plume: petrology and geochemistry of shield picrites. Earth and Planetary Science Letters, 168, 27-44.

Pollack H.N., Chapman D.S., 1977. On the regional variation of heat flow, geotherms and lithospheric thickness. Tectonophysics, 38, 279-296.

Putirka K., 2008. Thermometers and Barometers for Volcanic Systems. In: Putirka, K., Tepley, F. (Eds.), Minerals, Inclusions and Volcanic Processes, Reviews in Mineralogy and Geochemistry, Mineralogical Soc. Am., 69, 61-120.

Putirka K.D., 2017. Down the craters: where magmas stored and why they erupt. Methods and Further Reading. Supplement to February 2017 issue of Elements, 3(1), 11-16.

Putirka K.D., Johnson M., Kinzler R., Longhi J., Walker D., 1996. Thermobarometry of mafic igneous rocks based on clinopyroxene-liquid equilibria, 0-30 kbar. Contributions to Mineralogy and Petrology, 123, 92-108.

Putirka K.D., Mikaelian H., Ryerson F., Shaw H., 2003. New clinopyroxene-liquid thermobarometers for mafic, evolved, and volatile-bearing lava compositions, with applications to lavas from Tibet and the Snake River Plain, Idaho. American Mineralogist, 88, 1542-1554.

Qi Q., Taylor L.A., Zhou X., 1995. Petrology and geochemistry of mantle peridotite xenoliths from SE China. Journal of Petrology, 36, 55-79.

Sachtleben T.H., Seck H.A., 1981. Chemical control on the Al-solubility in orthopyroxene and its implications on pyroxene geothermometry. Contributions to Mineralogy and Petrology, 78, 157-65.

Shaw D.M., 1970. Trace element fractionation during anataxis. Geochimica et Cosmochimica Acta, 34, 237-243.

Sun S-S, McDonough W.F., 1989. Chemical and isotopic systematics of oceanic basalts: implications for mantle composition and processes. In Saunders A.D. and Norry, M.J. (eds) Magmatism in the Ocean Ba- sins. Geological Society Special Publication, 42, 313-345.

Takahashi E., 1986. Melting of a dry peridotite KLB-1 up to $14 \mathrm{Gpa}$ implications on the origin of peridotite upper mantle. J. Geophysical Research, 91, 93679382.

Takahashi E., Kushiro I., 1983. Melting of a dry peridotite at high pressure and basalt magma genesis. American Mineralogist, 68, 859-879.

Tamaki K., 1995. Upper mantle extrusion tectonics of southeast Asia and formation of western Pacific backarc basins. In: International Workshop: Cenozoic Evolution of the Indochina Peninsula, Hanoi/Do Son, April, p.89 (Abstract with Programs).

Tapponnier P., Lacassin R., Leloup P.H., Shärer U., Dalai Z., Haiwei W., Xiaohan L., Shaocheng J., Lianshang Z., Jiayou Z., 1990. The Ailao Shan/Red River metamorphic belt: Tertiary left-lateral shear between Indochina and South China. Nature, 343(6257), 431-437.

Tapponnier P., Peltzer G., La Dain A.Y., Armijo R., Cobbold P., 1982. Propagating extrusion tectonics in Asia: New insights from simple experiments with plasticine. Geology, 7, 611-616.

Tatsumoto M., Basu A.R., Huang W., Wang J., Xie G., 1992. $\mathrm{Sr}, \mathrm{Nd}$, and $\mathrm{Pb}$ isotopes of ultramafic xenoliths in volcanic rocks of eastern China: enriched components EMI and EMII in subcontinental lithosphere. Earth Planet Sci. Letters, 113, 107-128.

Taylor S.R., McLennan S.M., 1981. The composition and evolution of the continental crust: rare earth element evidence from sedimentary rocks. Philosophical Transactions of the Royal Society of London, 301, 381-399.

Tu K., Flower M.F.J., Carlson R.W., Xie G-H., 1991. Sr, $\mathrm{Nd}$, and $\mathrm{Pb}$ isotopic compositions of Hainan basalt (south China): Implications for a subcontinental lithosphere Dupal source. Geology, 19, 567-569.

Tu K., Flower M.F.J., Carlson R.W., Xie G-H., Zhang M., 1992. Magmatism in the South China Basin 1. Isotopic and trace-element evidence for an endogenous Dupal component. Chemical Geology, 97, 47-63.

Warren J.M., 2016. Global variations in abyssal peridotite compositions. Lithos, 248-251, 193-219. 
Vietnam Journal of Earth Sciences, 40(3), 207-227

Webb S.A., Wood B.J., 1986. Spinel pyroxene- garnet relationships and their dependence on $\mathrm{Cr} / \mathrm{Al}$ ratio. Contributions to Mineralogy and Petrology, 92, 471-480.

Wells P.R.A., 1977. Pyroxene thermometry in simple and complex systems. Contributions to Mineralogy and Petrology, 62, 129-139.

Whitford-Stark J.L., 1987. A survey of Cenozoic olcanism on mainland Asia, special paper, 213. Geological Society of America, 74p.
Workman R.K., Hart S.R., 2005. Major and trace element composition of the depleted MORB mantle (DMM). Earth and Planetary Science Letters, 231, 53-72.

Zhou P., Mukasa S., 1997. Nd-Sr-Pb isotopic, and major- and trace-element geochemistry of Cenozoic lavas from the Khorat Plateau, Thailand, sources and petrogenesis. Chemical Geology, 137, 175-193.

Zindler A., Hart S.R., 1986. Chemical geodynamics. Annual Review of Earth and Planetary Sciences, 14, 493-571. 